\title{
UCRL-ID-125298
}

\section{Desalination with Carbon Aerogel Electrodes}

\author{
Joseph C. Farmer \\ Jeffrey $H$. Richardson \\ David V. Fix
}

October 21, 1996

This is an informal report intended primarily for internal or limited external distribution. The opinions and conclusions stated are those of the author and may or may not be those of the Laboratory.

Work performed under the auspices of the U.S. Department of Energy by the Lawrence Livermore National Laboratory under Contract W-7405-Eng-48. 


\section{DISCLAIMER}

This document was prepared as an account of work sponsored by an agency of the Uaited States Government. Neither the United States Government nor the University of California nor any of their caployees, makes any warranty, express or bmplied, or assumes any legal liability or responsibility for the accuracy, completeness, or usefulaess of any information, apparatus, product, or process disclosed, or represents that its use would not infringe privately owmed rights. Reference herein to any specific commercial products, process, or service by trade name, trademart, manufacturer, or otherwise, does not necessarily constitute or imply its endorsement, recommendation, or favoring by the United States Government or the Universily of Callfornia. The views and opinions of authors expressed herein do not necessarily state or reflect those of the United States Government or the University of California, and shall not be used for ad vertising or product endorsement purposes.

This report has been reproduced directly from the best avallable cops.

Available to DOE and DOE contractors from the

Orfice of Scientific and Technical Information

P.O. Box 62, Oak Ridge, TN 37831

Prices available from (615) 576-8401, FTS 626-8401

Available to the public from the

National Technical Information Service

US. Department of Commerce

5285 Port Royal Rd.

Springfield, VA 22161 


\title{
Desalination with Carbon Aerogel Electrodes
}

\author{
Joseph C. Farmer, Jeffrey H. Richardson and David. V. Fix \\ Chemistry and Materials Science Department \\ Lawrence Livermore National Laboratory \\ Livermore, California 94550
}

October 21, 1996

\begin{abstract}
An electrically-regenerated electrosorption process known as carbon aerogel $\mathrm{CDI}$ has been developed by Lawrence Livermore National Laboratory (LLNL) for continuously removing ionic impurities from aqueous streams. A salt solution flows in an unobstructed channel formed by numerous pairs of parallel carbon aerogel electrodes. Each electrode has a very high BET surface area $\left(2.0-5.4 \times 10^{6} \mathrm{ft}^{2} \mathrm{lb}^{-1}\right.$ or $\left.400-1100 \mathrm{~m}^{2} \mathrm{~g}^{-1}\right)$ and very low electrical resistivity $(\leq 40 \mathrm{~m} \Omega$ $\mathrm{cm})$. BET surface areas of $1.3 \times 10^{7} \mathrm{ft}^{2} \mathrm{lb}^{-1}\left(2600 \mathrm{~m}^{2} \mathrm{~g}^{-1}\right)$ have been achieved with thermal activation. After polarization, anions and cations are removed from the electrolyte by the imposed electric field and electrosorbed onto the carbon aerogel. The solution is thus separated into two streams, concentrated brine and purified water. Based upon this preliminary analysis, carbon aerogel CDI appears to be an energy-efficient alternative to evaporation, electrodialysis and reverse osmosis. The energy required by this process is approximately $Q V / 2$, where $Q$ is the stored electrical charge and $V$ is the voltage between the electrodes, plus losses due to parasitic electrochemical reactions, electrical resistance and pressure drop. The estimated energy requirement for $\mathrm{SW}$ desalination is $\sim 18-27 \mathrm{Wh} \mathrm{gal}^{-1}\left(17-26 \mathrm{~kJ} \mathrm{~L}^{-1}\right)$, depending upon cell voltage and flow rate. The estimated requirement for $\mathrm{BW}$ desalination is substantially less, $\sim 1.2-2.5 \mathrm{Wh}$ $\mathrm{gal}^{-1}\left(1.1-2.4 \mathrm{~kJ} \mathrm{~L}^{-1}\right)$ at $1600 \mathrm{ppm}$. These estimates assume that stored electrical energy is reclaimed during regeneration (electrical discharge). Such low inherent energy requirements and the possibility of energy recovery may make this process attractive for desalination.
\end{abstract}

\section{Introduction}

Background. Throughout time man has used fresh water for drinking, industrial, and agricultural purposes, and has settled where suitable water was available, as stated by Summers [1]. Progressive industrialization and expansion of irrigation agriculture add to the ever increasing use of fresh water. The rapid increase of the global population and the non-uniform distribution of fresh water around the world has motivated research into the development of various desalination methods. If pure water could be economically obtained from sea water, it would have a dramatic affect on our future standard of living, as competition for fresh water increases. President John F. Kennedy said, "If we could ever competitively, at a cheap rate, get fresh water from salt water, ... this would be in the long-range interests of humanity, ... (and) would dwarf any other scientific accomplishment." Desalination of sea water (SW) and brackish water (BW) offers great potential for increasing the availability of fresh water. The concentration of salt in $\mathrm{SW}$ is typically $\sim 35,000 \mathrm{ppm}$, though it may reach $50,000 \mathrm{ppm}$ in some areas. In California, 
most BWs have concentrations between 800 to $3200 \mathrm{ppm}$. The concentration of salt in BW rarely exceeds $10,000 \mathrm{ppm}$. These levels must be reduced to $\sim 500 \mathrm{ppm}$ for drinking water, and to $\sim 50 \mathrm{ppm}$ for agricultural use. Until now, we have been paying a low price for fresh water, however the cost may increase dramatically as demand increases and we are forced to use other methods to avail ourself of fresh water.

\section{Desalination Processes}

Desalination Options. Most large-scale desalination processes in the world are based on variations of evaporation and distillation. These energy-intensive, thermal processes require heat that is derived from burning fossil or nuclear fuel. Despite the huge energy requirements, thermal processes are favored for $\mathrm{SW}$ desalination since large production rates are possible with reasonable investments in capital equipment. Electrodialysis (ED) and reverse osmosis (RO) systems are more energy efficient, but require expensive and troublesome membranes. Membranes are plagued by chemical degradation, biological fouling and inorganic scale formation problems, and must be replaced frequently. Membrane processes have been used for desalination of SW, but are more often considered for the desalination of reservoirs of brackish water (BW). In some cases, capacitive deionization (CDI) with carbon aerogel electrodes may serve as an energy-efficient alternative to thermal and membrane desalination processes. Carbon aerogel is an ideal electrode material because of its low electrical resistivity $(\leq 40 \mathrm{~m} \Omega \mathrm{cm})$, high specific surface area $\left(2.0-5.4 \times 10^{6} \mathrm{ft}^{2} \mathrm{lb}^{-1}\right.$ or $\left.400-1100 \mathrm{~m}^{2} \mathrm{~g}^{-1}\right)$, controllable pore size distribution $(\leq 50 \mathrm{~nm})$, and monolithic structure. Note that surface areas as high as $1.3 \times 10^{7} \mathrm{ft}^{2} \mathrm{lb}^{-1}\left(2600 \mathrm{~m}^{2}\right.$ $\left.\mathrm{g}^{-1}\right)$ have been achieved with activation.

Thermal Processes. Thermal processes are the oldest and most commonly used methods of desalination in the world. The thermal efficiency of such a process is usually called the "performance ratio" or "economy" and is usually defined as the pounds of distillate produced per $1000 \mathrm{Btu}$ of heat input. Here, the total required energy is given in units of $\mathrm{Wh} \mathrm{gal}^{-1}\left(\mathrm{~kJ} \mathrm{~L}^{-1}\right)$. Evaporative distillation serves as the major source of fresh water in the Middle East. Early designs are of the submerged-tube, multiple-effect type. In such systems, steam is fed through tubes submerged in a stagnant pool of brine, thereby causing the brine to boil. Evaporated water is condensed as pure, salt-free water. Salts remain in the brine phase, which becomes more concentrated. Energy recovery is accomplished by heat transfer from the product to the feed. Scale formation on heat transfer surfaces lowers the thermal efficiency of the process and is exacerbated by high operating temperatures, which leads to localized supersaturation and precipitation. Multistage flash evaporation (MSF) is an alternative thermal process that was developed to improve process efficiency and to minimize operating problems associated with scale formation. Since the introduction of MSF in the 1960 's, about $56 \%$ of the total installed desalination plant capacity has been MSF [2]. In this process, salt water is introduced into a low pressure chamber where it undergoes flash evaporation. Note that vapor can be produced from a liquid at its boiling point by adding heat at constant pressure and temperature (boiling), or by reducing pressure at constant temperature (flashing). The amount of heat that is lost from the process is minimized by using several counter-current stages, each at a lower temperature and pressure than the preceeding stage. Energy recovery is improved by adding stages. Since heat 
transfer surfaces in MSF processes are maintained at lower temperatures than those in submerged-tube multiple-effect systems, problems associated with scale formation are less. A typical MSF system consumes $\sim 320 \mathrm{Wh} \mathrm{gal}^{-1}\left(304 \mathrm{~kJ} \mathrm{~L}^{-1}\right.$ ) for SW desalination, compared to the theoretical minimum of $\sim 4.2 \mathrm{Wh} \mathrm{gal}^{-1}\left(4.0 \mathrm{~kJ} \mathrm{~L}^{-1}\right)$. Note that a simple evaporator without energy recovery would require more than $2720 \mathrm{Wh} \mathrm{gal}^{-1}\left(2587 \mathrm{~kJ} \mathrm{~L}^{-1}\right)$. Energy recovery can be enhanced by using mechanical vapor recompression (MVC). Mechanical compression is used to elevate the temperature of vapor from the evaporator to a point where it can be used to drive the evaporator. The hot compressed vapor loses its latent heat to the incoming feed and condenses, yeilding salt-free product. Since the temperature differential between the hot and cold side of the heat transfer surface is only $7-9^{\circ} \mathrm{F}\left(4-5^{\circ} \mathrm{C}\right)$, the required energy and rates of scale formation are both low. A typical MVC system consumes $\sim 30-41 \mathrm{Wh} \mathrm{gal}^{-1}\left(29-39 \mathrm{~kJ} \mathrm{~L}^{-1}\right)$. See Table 1 for published energy requirements for $\mathrm{SW}$ desalination processes [2].

Reverse Osmosis. Reverse osmosis (RO) is a separation processes which uses membranes to selectively remove water from a salt solution. In conventional osmosis, water or solvent flows through a semipermeable membrane from a less concentrated solution to an area of higher concentration. This normal osmotic flow can be reversed by applying pressure in excess of the osmotic pressure. The flow through the semipermeable membrane is governed by Equation 1:

$F_{w}=A(\Delta p-\Delta \pi)$

where $F_{w}$ is the water flux $\left(\mathrm{g} \mathrm{cm}^{-2} \mathrm{~s}^{-1}\right), A$ is the water permeability constant $\left(\mathrm{g} \mathrm{cm}^{-2} \mathrm{~s}^{-1} \mathrm{~atm}^{-1}\right), \Delta p$ is the differential pressure applied across the membrane (atm), and $\Delta \pi$ is the osmotic pressure differential across the membrane (atm) [3a]. The osmotic pressure is a function of salt concentration and is represented by Equation 2:

$$
\Delta \pi=1.12(T+273) \sum_{j} m_{j}
$$

where $\Delta \pi$ is the osmotic pressure (psi), $T$ is the temperature $\left({ }^{\circ} \mathrm{C}\right)$, and $m_{i}$ is the molality of the ith ionic or non-ionic constituent [3b]. A rule of thumb that works well with natural water, based on $\mathrm{NaCl}$, is that the osmotic pressure increases by approximately $0.01 \mathrm{psi}\left(6.8 \times 10^{-4} \mathrm{~atm}\right)$ for each $\mathrm{ppm}\left(\mathrm{mg} \mathrm{L}^{-1}\right)$ increase in salt concentration. Applying this rule to $\mathrm{SW}$, the osmotic pressure is estimated to be about $350 \mathrm{psi}(24 \mathrm{~atm})$. The salt flow through a semipermeable membrane can be expressed by Equation 3:

$$
F_{s}=B\left(C_{1}-C_{2}\right)=B \Delta C
$$

where $B$ is the salt permeability constant $\left(\mathrm{cm} \mathrm{s}^{-1}\right)$ and $\Delta C=C_{I}-C_{2}$ is the concentration gradient across the membrane $\left(\mathrm{g} \mathrm{cm}^{-3}\right)$ [3a]. RO with cellulose acetate, polyamide or other polymer semipermeable membranes can be used to desalinate $\mathrm{BW}$ or $\mathrm{SW}$. Usually, membranes are incorporated into plate-and-frame, tubular, or spiral-wound modular units. An RO-based desalination process usually consists of several of these modules connected together in seriesparallel arrays. The processed feedwater is separated into two streams, permeate and brine. The 
permeate passes through the membranes due to the pressure gradient while the brine is continuously rejected. Typical systems reject brine with a salt concentration of two to four times ( $2 \mathrm{X}$ to $4 \mathrm{X}$ ) greater than that of the feed. Since mechanical energy is used in lieu of heat energy, RO systems operate at ambient temperature and avoid some of the problems associated with high-temperature thermal processes. RO systems do suffer from problems such as concentration polarization, chemical degradation, biological fouling, and scaling of membranes. Concentration polarization at the brine-membrane interface increases the mass transfer resistance and requires additional pressure to overcome. Furthermore, it causes localized supersaturation and precipitation, which exacerbates scale formation. As pores in the membrane become blocked, the flux of water at a constant applied pressure will reduce. In order to avoid such problems, feed water must be pretreated. A typical RO system for SW desalination requires $\sim 25-36 \mathrm{Wh}$ $\mathrm{gal}^{-1}$ (24-34 $\left.\mathrm{kJ} \mathrm{L}^{-1}\right)$ depending upon the use of energy recovery [2]. Only 5.3-8.5 Wh gall (5.0$8.1 \mathrm{~kJ} \mathrm{~L}^{-1}$ ) are required for BW desalination [4]. Extremely large RO plants have been built and successfully operated. For example, the Yuma Desalting Plant in Yuma, Arizona is the largest RO facility in the world and is operated by the U.S. Department of Interior, Bureau of Reclamation. Construction of this plant was authorized by the Colorado River Basin Salinity Control Act (PL 93-320), legislation passed by the U.S. Congress in 1977. The objective of this monumental project is to enable the United States to satisfy conditions of a treaty with Mexico (Treaty TS 994, 1944; Ammended with Minute No. 242, 1977). Under that agreement, the United States agreed that the salinity of water delivered to Mexico at Morelos Dam would not exceed the salinity level at the Imperial Dam by more than $115 \pm 39 \mathrm{ppm}$. The Imperial Dam is 27 miles $(43 \mathrm{~km})$ upstream of the Morelos Dam. The Yuma Desalting Plant uses cellulose acetate RO membranes to desalinate as much as $72.4 \times 10^{6} \mathrm{gal} \mathrm{d}^{-1}\left(275 \times 10^{6} \mathrm{~L} \mathrm{~d}^{-1}\right)$ of saline drainage water from farmlands east of Yuma. The salt concentration is lowered from 3000 to $\leq$ $300 \mathrm{ppm}$ with a differential pressure of $\sim 362 \mathrm{psi}(25 \mathrm{~atm})$. The product $(\sim 300 \mathrm{ppm})$ and unprocessed drainage water $(\sim 3000 \mathrm{ppm})$ are blended and sent to the Colorado River, while concentrated brine $(\sim 10,000 \mathrm{ppm})$ is rejected and sent to the Santa Clara Marsh at the Gulf of California. This RO-based desalination plant enables the United States salvage drainage water that otherwise would be too saline to deliver to Mexico, thereby saving up to 78,500 acre-feet $\left(97 \times 10^{6} \mathrm{~m}^{3}\right)$ of Colorado River water per year. The Yuma Desalting Plant is not being operated at the present time since water quality requirements can be temporarily met without it. It remains in a state of readiness.

Electrodialysis. In a conventional electrodialysis (ED) cell, several pairs of anion and cation exchange membranes are placed between a pair of planar electrodes, one serving as the anode and the other serving as the cathode. Isolated compartments are formed between each adjacent pair of anion and cation exchange membranes. The electric field imposed by polarization of the cell causes the electromigration of ions, with negatively-charged anions moving through anion exchange membranes towards the positively-charged anode, and positively-charged cations moving through the cation exchange membrane towards the negatively-charged cathode. Ions are forced out of compartments with the same polarity as the cell (even-numbered) and concentrated in compartments having opposite polarity (odd-numbered). Relatively pure water is withdrawn from even-numbered compartments, while the brine phase is recylced to the oddnumbered compartments. Electrolysis causes oxygen evolution at the anode and hydrogen 
evolution at the cathode. These gaseous reaction products must be continuously removed from the cell. Other electrochemical reactions are also possible, depending upon the impurity ions. Water in the anode compartment becomes acidic due to the accumulation of hydrogen ions, while water in the cathode compartment becomes alkaline due to the accumulation of hydroxyl ions. Elevated $\mathrm{pH}$ in the cathode compartment promotes precipitation and accelerates scale formation, and makes rinsing of the electrodes mandatory. Extensive pretreatment of the feedwater is also required to reduce membrane degradation and fouling. Process costs are directly related to the concentration of salt in the feedwater, ie., the amount of current necessary to produce the separation. ED requires $\sim 7.7 \mathrm{Wh} \mathrm{gal}^{-1}\left(7.3 \mathrm{~kJ} \mathrm{~L}^{-1}\right)$ for desalination of a typical $\mathrm{BW}$ [4] and 60-75 Wh gal ${ }^{-1}\left(57-71 \mathrm{~kJ} \mathrm{~L}^{-1}\right)$ for desalination of SW [5-6].

Flow-Through Capacitors with Activated Carbon Electrodes. There were attempts to desalinate water with activated carbon electrodes in the early 1960 's, however, limitations of the electrode materials available at that time prevented further development. The University of Oklahoma appears to have been the first group to use flow-through capacitors with activated carbon electrodes for desalination, with seminal publications that appeared in the early 1960's [7,8]. Activated carbon powders and fibers were held together in electrodes by a variety of polymeric binders. Johnson et al. conducted similar studies of reversible electrosorption with beds of activated carbon in the early 1970's [9-11]. Johnson's work prompted Newman to develop a comprehensive theoretical model for the capacitive charging of porous carbon electrodes [12]. Additional work was done in Israel several years later and published in the 1980's [13-15]. The work in Israel also explored chromatographic separation. Several practical problems were encountered with these conventional activated carbon systems. For example, the performance (electrosorption capacity) of activated carbon was found to degrade with time. In electrodes made with polymeric binders, significant fractions of the activated carbon surface was occluded. Electrochemical cells that used flow-through beds of activated carbon powder as electrodes required membrane separators for electrical insulation and to prevent entrainment of individual particles in the flow. Furthermore, flow through such porous media is characterized by high pressure drop. Process efficiency is lowered by large potential drops that develop in thick electrodes, which include packed beds. Finally, early activated-carbon systems had no provisions for the continuous production of pure water, or for the recovery of stored electrical energy. Eventually, this approach to desalination was abandoned.

\section{Capacitive Deionization with Carbon Aerogel Electrodes}

Principle of Operation. More recently, an electrochemical process for the capacitive deionization (CDI) of water with stacks of carbon aerogel composite (CAC) electrodes has been developed by Lawrence Livermore National Laboratory [16-24]. An aqueous solution of $\mathrm{NaCl}$, $\mathrm{Na}_{2} \mathrm{CO}_{3}, \mathrm{Na}_{2} \mathrm{SO}_{4}$ or another salt is passed between numerous pairs of carbon aerogel electrodes, each having a very high BET surface area $\left(2.0-5.4 \times 10^{6} \mathrm{ft}^{2} \mathrm{lb}^{-1}\right.$ or $\left.400-1100 \mathrm{~m}^{2} \mathrm{~g}^{-1}\right)$ and exceptionally low electrically resistivity $(\leq 40 \mathrm{~m} \Omega \mathrm{cm})$. Measured electrosorption capacities, extrapolated to $0.03 \mathrm{~N}$, are on the order of $6 \times 10^{-3} \mathrm{lb}_{\mathrm{NaCl}} \mathrm{lb}_{\mathrm{C}}{ }^{-1}\left(20 \times 10^{-5}\right.$ equiv $\left.\mathrm{g}^{-1}\right)$. After polarization, ions such as $\mathrm{Na}^{+}$and $\mathrm{Cl}^{-}$are removed from the electrolyte by the imposed electric field and held in electric double layers formed at the surfaces of electrodes. The Gouy-Chapman 
Theory or the Stern Modification of that theory can be used to describe the effect of an imposed electric field on the surface charge density of the electric double layer $[25,26]$. As desired, the effluent from the cell is purified water. This process is also capable of simultaneously removing a variety of other impurities. For example, dissolved heavy-metal ions can be removed by reversible electrosorption [27] or by electrodeposition [28-31], in contrast to simple double-layer charging. In the specific case of carbon aerogel CDI, LLNL has investigated a broad range of cell voltages [16-24]. The best performance (salt removal) was achieved at $\sim 1.2-1.3 \mathrm{~V}$, though operation at $0.6 \mathrm{~V}$ was found to be possible. Successful testing was done at solution conductivities of $4,59,294,588$ and $5,882 \mathrm{ppm}\left(7,100,500,1000\right.$ and $\left.10,000 \mu \mathrm{S} \mathrm{cm}^{-1}\right)$. In routine single-pass experiments, more than $99 \%$ of the salt was removed from a $59 \mathrm{ppm}(100 \mu \mathrm{S}$ $\mathrm{cm}^{-1}$ ) feed stream. After the carbon aerogel electrodes became saturated with salt, breakthrough was observed. Electrodes are regenerated by electrical discharge prior to breakthrough in process applications, which allows the captured salt ions are released into a relatively small, concentrated purge stream.

Carbon Aerogel Electrodes. Carbon aerogel is an ideal electrode material because of its low electrical resistivity $(\leq 40 \mathrm{~m} \Omega \mathrm{cm})$, high specific surface area $\left(2.0-5.4 \times 10^{6} \mathrm{ft}^{2} \mathrm{lb}^{-1}\right.$ or $400-1100$ $\left.\mathrm{m}^{2} \mathrm{~g}^{-1}\right)$, and controllable pore size distribution $(\leq 50 \mathrm{~nm})$. Note that thermal and chemical activation has been used to achieve BET surface areas of $1.3 \times 10^{7} \mathrm{ft}^{2} \mathrm{lb}^{-1}\left(2600 \mathrm{~m}^{2} \mathrm{~g}^{-1}\right)$ [32]. Resorcinol-formaldehyde (RF) aerogels and their carbonized derivatives were first developed by LLNL [33-36]. Monolithic sheets of this material were made by infiltrating a resorcinolformaldehyde solution into a porous carbon paper (Textron Specialty Materials, Lowell, MA), curing the wetted paper between glass plates in a closed vessel, and then pyrolizing in an inert atmosphere. The exceptionally high conductivity of this carbon aerogel composite (CAC), in contrast to loosely bonded carbon powders or activated carbon fiber cloths (ACFCs), is attributable to its monolithic structure which is composed of interconnected, covalently-bonded carbon particles, each having a diameter of $\sim 12 \mathrm{~nm}$. In contrast to electrodes made from activated carbon powders and fibers, the activation energy for carrier transport in carbon aerogel is relatively small. These very desirable characteristics have enabled LLNL to use CAC sheets as electrodes in novel supercapacitors with high energy density and high power density [37]. However, these energy-storage devices were not designed to permit electrolyte flow and required membranes to physically separate the electrodes. As discussed here, LLNL has now used CAC electrodes in a variety of configurations to remove ionic contaminants from water. The CAC used to generate the data shown in this publication was produced at LLNL, as well as at GenCorp-Aerojet Plant in Sacramento, California. During this first commercial production campaign, it was demonstrated that a large quantity of high-quality CAC sheets $\left(4000 \mathrm{ft}^{2}\right.$ or 372 $\mathrm{m}^{2}$ ) could be mass produced at an apparent cost of approximately $\$ 50$ per square foot. It may be possible to reduce the cost to well below $\$ 1-2$ per square foot in the future.

Electrochemical Cells. Double-sided electrodes for the electrochemical cell were made by gluing two sheets of the CAC to both sides of a titanium plate with graphite-filled epoxy. The titanium plate served as both a current collector and a structural support. Each sheet of CAC was 4 in $\times 8$ in $\times 0.010$ in $(10.16 \mathrm{~cm} \times 20.32 \mathrm{~cm} \times 0.0254 \mathrm{~cm})$ and had a total estimated BET surface area of $\sim 3.4 \times 10^{4} \mathrm{ft}^{2}\left(3.2 \times 10^{7} \mathrm{~cm}^{2}\right)$. A typical stack of 150 double-sided, titanium-supported 
electrodes had a total estimated BET surface area of approximately $\sim 1.0 \times 10^{7} \mathrm{ft}^{2}\left(9.4 \times 10^{9} \mathrm{~cm}^{2}\right)$. Electrolyte flowed through the stack in open channels formed between adjacent electrodes. An electrode separation of $\sim 0.027$ in $(0.069 \mathrm{~cm})$ was maintained by rubber compression seals. By arranging the electrodes so that orifices alternate from one side of the stack to the other, flow from the bottom of the stack to the top was serpentine.

Automated Control and Potential-Swing Operation. A prototypical potential-swing system has been developed $[24,38]$. Ultimately, such synchronous operation will be essential for energy recovery and will require the degree of automation and sophistication that has now been demonstrated. This prototype can produce a continuous flow of both product water and concentrate by operating two stacks of electrodes in parallel. One stack purifies while the other is electrically regenerated. Flow is generated by a programmable, magnetically-coupled, screw pump with a 304 stainless steel head. All lines are made of Teflon and had a nominal diameter of $1 / 4$ in $(0.635 \mathrm{~cm})$. The cells are polarized by programmable power supplies that have a voltage range of 0 to $12 \mathrm{~V}$ or a current range of 0 to $60 \mathrm{~A}$. Sensors were placed on the inlet and outlet lines of the electrode stack. Electrical conductivity of the solution, $\mathrm{pH}$, individual ion concentrations, and temperature are continuously monitored. The system is controlled by a personal computer. A single AT-MIO-16DH data acquisition board, installed in the computer, provides the interface to the Input-Output (I/O) Signal Subsystem. The I/O subsystem consists of a single 12-slot Signal Conditioning Extension Interface (SCXI) chassis. The chassis contains seven 8-channel analog-to-digital (A/D) modules to measure flow, level, pressure, temperature, $\mathrm{pH}$, and conductivity; two 16-channel single-pole double-throw (SPDT) relay modules for controlling pumps and valves; and one 6-channel digital-to-analog (D/A) module for controlling power supply voltages and pump speed. The SCXI hardware provides multiplexing, filtering, isolation, and amplification for the process signals. The operating system is DOS v6.22 running Windows v3.1. LabVIEW v3.1 software, running under Windows, is used for data acquisition and control. LabVIEW is a graphical programming environment which provides integrated tools for acquisition, control, analysis, and presentation, as well as connectivity to serial, parallel, voltage, current loop, RTD, thermistor, and relay communication interfaces. Data acquisition and control software is optimized and converted to compiled run-time code. Operator input is via a mouse and keyboard.

\section{Surface Area and Electrosorption Capacity}

Interpretation of BET Surface Areas. It is noteworthy that activated carbon powders with Brunauer-Emmet-Teller (BET) surface areas as high as $1.5 \times 10^{7} \mathrm{ft}^{2} \mathrm{lb}^{-1}\left(3000 \mathrm{~m}^{2} \mathrm{~g}^{-1}\right)$ are readily available. However, much of the surface area in such materials is located inside pores having diameters less than $1 \mathrm{~nm}$. It is believed that the electrochemically active area is only a fraction of the BET surface area. BET analyses are probably misleading since gas molecules can penetrate much smaller pores than a typical electrolyte. For example, the bond length of $\mathrm{N}_{2}$ is only 0.1 $\mathrm{nm}$. It is very doubtful that this level of porosity contributes to electrochemical double layer formation since electrolyte penetration and double layer formation are questionable on this scale. From the Gouy-Chapman theory, as well as the Stern modification of that theory, it is believed that a fully-developed electric double layer on a planar electrode with no detrimental shielding effects would require much greater distances for full development. In the case of a 1:1 
electrolyte in water at $25^{\circ} \mathrm{C}$, the characteristic thickness of the diffuse layer ranges from $1 \mathrm{~nm}$ at a concentration of $0.1 \mathrm{M}$ to $30 \mathrm{~nm}$ at $10^{-4} \mathrm{M}[26,27]$. Though BET surface areas are frequently quoted, the electrosorption capacity, given as equivalents adsorbed per gram of carbon is believed to be a more relevant measure of electrode performance $[7,8]$.

From the Gouy-Chapman theory developed for simple planar electrodes, one might expect the surface charge density to have a square root dependence on electrolyte concentration [25,26]. In the case of dilute aqueous solutions at $25^{\circ} \mathrm{C}$, the following expression should be obeyed by both anodes and cathodes:

$$
\sigma=11.7 \sqrt{C} \sinh \left(19.5 z \phi_{0}\right)
$$

where $\sigma$ is the surface charge density $\left(\mathrm{mC} \mathrm{cm}^{-2}\right), C$ is the electrolyte concentration $\left(\mathrm{mol} \mathrm{L}^{-1}\right), z$ is the ionic charge, and $\phi_{0}$ is the electrode potential $(\mathrm{mV})$. However, double layer formation on carbon electrodes is much more complicated. For example, cathode capacities are much higher than corresponding anode capacities [7,8]. This is attributed to the cation affinity of carbonyl groups on the electrode surface. Therefore, the electrosorption capacity of an electrochemical cell built with porous carbon electrodes is probably limited by its ability to accomodate anions.

Recent data from experiments with $\mathrm{NaCl}$ are illustrated by Figures 1 and 2 . Figure 1 shows the electrosorption of $\mathrm{Na}^{+}$and $\mathrm{Cl}^{-}$on 54 double-sided CAC electrodes, each having a width of 4 in and a length of 8 in $(10.16 \mathrm{~cm} \times 20.32 \mathrm{~cm})$. The quantity of electrosorbed $\mathrm{NaCl}(\mathrm{Y})$ was calculated from the minimum in electrolyte concentration $\left(\mathrm{X}_{1}\right)$, reached after polarizing the electrodes for about 55 minutes. The stack of electrodes was maintained at a cell voltage of 1.2 $\mathrm{V}\left(\mathrm{X}_{2}\right)$ while $0.93 \mathrm{gal}(3.5 \mathrm{~L})$ of electrolyte was continuously recycled at a rate of $1.59 \mathrm{gal} \mathrm{h}^{-1}$ $\left(\mathrm{X}_{3}, 100 \mathrm{ml} \mathrm{min}^{-1}\right)$. Results for 59,278 and $588 \mathrm{ppm}\left(100,500\right.$ and $\left.1000 \mu \mathrm{S} \mathrm{cm}^{-1}\right) \mathrm{NaCl}$ solutions are compared. Figure 2 shows electrosorption on 100 double-sided CAC electrodes with the same dimensions as those represented by Figure 1. Approximately 0.79 gal ( $3 \mathrm{~L}$ ) of 59 $\operatorname{ppm}\left(100 \mu \mathrm{S} \mathrm{cm}^{-1}\right) \mathrm{NaCl}$ solution was continuously recycled at a rate of $1.59 \mathrm{gal} \mathrm{h}^{-1}(100 \mathrm{ml}$ $\min ^{-1}$ ). Results for 0.6 and $1.2 \mathrm{~V}$ are compared. Multiple variable regression analysis of this data was used to determine the dependence of the anion capacity, $Y$, on equilibium electrolyte concentration, $\mathrm{X}_{1}$, and cell voltage, $\mathrm{X}_{2}$. The effects of flow rate were not taken into consideration. The results are summarized by Equation 5:

$$
Y=1.3959 X_{1}^{0.21718} X_{2}^{2.5883}
$$

where $\mathrm{Y}$ has the units of $10^{-5}$ equivalents per gram of carbon aerogel (based on the anode mass alone), $X_{1}$ has the units of $10^{-3}$ equivalents per liter of solution, and $X_{2}$ is given in volts. The agreement between the correlation and experimental data is very good, as illustrated by Figure 3 . This is reflected in the calculated multiple-variable regression coefficient, $R^{2}$, which is 0.966 . A second regression analysis was done, which also accounted for the effects of flow rate, $\mathrm{X}_{3}$. The results are summarized by Equation 6: 
$Y=2.6730 X_{1}^{0.27484} X_{2}^{2.7024} X_{3}^{-0.27814}$

where $\mathrm{X}_{3}$ is given in $\mathrm{ml} \mathrm{min}^{-1}$. Here too the agreement between the correlation and experimental data is very good, as illustrated by Figure 4 . The calculated multiple-variable regression coefficient, $\mathrm{R}^{2}$, is 0.942 . Since $\mathrm{Y}$ and $\mathrm{X}_{1}$ are directly proportional to $\sigma$ and $C$, respectively, one could reasonably expect:

$Y \propto X_{1}^{0.5}$

It is believed that the failure to observe square-root concentration dependence is due to selfshielding effects experienced by the porous carbon electrodes.

\section{Minimum Energy Required for Separation}

The minimum work of separation of a feed mixture into impure products at constant temperature and pressure can be computed with Equation 8 [39]:

$W_{\min , T}=-R T\left(\sum_{j} x_{j F} \ln \left(\gamma_{j F} x_{j F}\right)-\sum_{i} \phi_{i} \sum_{j} x_{j i} \ln \left(\gamma_{j i} x_{j i}\right)\right)$

where $\phi_{i}$ is the molar fraction of feed entering product $i, x_{j i}$ is the mole fraction of component $j$ in product $i$, and $\gamma_{j i}$ is the activity coefficient of component $j$ in product $i$. For a binary mixture, Equation 9 becomes:

$W_{\min , T}=-\frac{R T}{x_{A 1}-x_{A 2}}\left\{\begin{array}{c}\left(x_{A F}-x_{A 2}\right)\left[x_{A 1} \ln \frac{\gamma_{A F} x_{A F}}{\gamma_{A 1} x_{A 1}}+\left(1-x_{A 1}\right) \ln \frac{1-x_{A F}}{1-x_{A 1}}\right] \\ +\left(x_{A 1}-x_{A F}\right)\left[x_{A 2} \ln \frac{\gamma_{A F} x_{A F}}{\gamma_{A 2} x_{A 2}}+\left(1-x_{A 2}\right) \ln \frac{1-x_{A F}}{1-x_{A 2}}\right]\end{array}\right\}$

The Debye-Huckel model [40] can be used to estimate the activity coefficient of component $j$ :

$\ln \gamma_{j}=-\frac{z_{j}^{2} \alpha^{\prime} \sqrt{I^{\prime}}}{1+B^{\prime} a \sqrt{I^{\prime}}}$

where $a$ is the exclusion distance of a central ion located at the origin, $z_{j}$ is the valence of species $j, I$ ' is the molar ionic strength, and $\alpha^{\prime}$ and $B^{\prime}$ are the Debye-Huckel parameters. The molar ionic strength is:

$$
I^{\prime}=\frac{1}{2} \sum_{j} z_{j}^{2} c_{j}
$$


where $c_{j}$ is the molar concentration of species $j$. The Debye Huckel parameters are defined as:

$$
\begin{aligned}
& B^{\prime}=\frac{F}{\sqrt{\varepsilon R T / 2}} \\
& \alpha^{\prime}=\frac{F e}{8 \pi \varepsilon R T} B
\end{aligned}
$$

where $R$ is the universal gas constant, $T$ is the absolute temperature, $F$ is Faraday's constant, $e$ is the electronic charge, and $\varepsilon$ is the permittivity. As the ionic strength goes to zero, the DebyeHuckel limiting law becomes:

$$
\ln \gamma_{j} \approx-z_{j}^{2} \alpha^{\prime} \sqrt{I^{\prime}}
$$

Equations 9 through 14 were used to calculate the minimum energy requirements for desalination as a function of $\mathrm{NaCl}$ concentration. Results are summarized in Table 2 and in Figures 5 and 6. The minimum energy required for the desalination of a $1600 \mathrm{ppm} \mathrm{NaCl}$ solution (surrogate $\mathrm{BW}$ ) is $\sim 0.37 \mathrm{Wh} \mathrm{gal}^{-1}\left(0.35 \mathrm{~kJ} \mathrm{~L}^{-1}\right)$ whereas the minimum energy required to desalinate a $35,000 \mathrm{ppm}$ $\mathrm{NaCl}$ solution (surrogate $\mathrm{SW}$ ) is $\sim 4.2 \mathrm{Wh} \mathrm{gal}^{-1}\left(4.0 \mathrm{~kJ} \mathrm{~L}^{-1}\right)$. In both cases, it was assumed that the product contained $10 \mathrm{ppm} \mathrm{NaCl}$.

\section{Electrical Energy Requirement}

The energy stored in the electrochemical cell during charging (deionization) can be estimated from the expression for an ideal capacitor:

$U_{\text {stored }}=\frac{1}{2} Q V$

where $Q$ is the stored electrical charge and $V$ is the cell voltage. Stored energy is available for recovery during discharge (regeneration). Equation 16 accounts for the energy consumed by parasitic electrochemical reactions:

$U_{\text {parasitic }}=V \int_{0}^{t} I_{p}(t) d t$

where $I_{p}(t)$ is the instantaneous current due to parasitic charge-transfer reactions and $t$ is the time required for deionization. Ohmic losses must also be accounted for:

$$
U_{\text {ohmic }}=\int_{0}^{t} R(t)\left[I_{c}(t)+I_{p}(t)\right]^{2} d t
$$


where $I_{c}(t)$ is the instantaneous current due to deionization and $R(t)$ is the instantaneous electrical resistance. Note that $I_{p}(t), I_{c}(t)$ and $R(t)$ are spatially-averaged quantities, representing the entire stack of electrodes. At this point, a reasonable approximation for an order-of-magnitude esimate can be derived by treating the currents and the resistance as a time-average quantities.

$$
\begin{aligned}
& U_{\text {parassitc }} \approx V I_{p} \Delta t \\
& U_{\text {ohmic }} \approx R\left\{\left(\frac{Q}{\Delta t}\right)+I_{p}\right\}^{2} \Delta t
\end{aligned}
$$

The electrical energy requirements for this process are found in Table 2. Cases 1 through 3 assume that the cell voltage is $1.2 \mathrm{~V}$. The flow rate through each 150 -electrode stack is assumed to be $1.59 \mathrm{gal} \mathrm{h}^{-1}\left(100 \mathrm{ml} \mathrm{min}^{-1}\right)$ in Case $1 ; 0.40 \mathrm{gal} \mathrm{h}^{-1}\left(25 \mathrm{ml} \mathrm{min}^{-1}\right)$ in Case 2; and $0.16 \mathrm{gal} \mathrm{h}^{-1}$ $\left(10 \mathrm{ml} \mathrm{min-1)}\right.$ in Case 3. Case 4 assumes a cell voltage of $0.6 \mathrm{~V}$ and a flow rate $0.40 \mathrm{gal} \mathrm{h}^{-1}(10$ $\mathrm{ml} \mathrm{min}{ }^{-1}$ ). The estimate of total energy requirement assumes $70 \%$ recovery of stored electrical energy and $70 \%$ pumping efficiency. Observed parasitic current densities, based on the CAC sheet size, were scattered from 5 to $23 \mu \mathrm{A} \mathrm{cm}^{-2}$. For the purpose of this analysis, a representative value of $9 \mu \mathrm{A} \mathrm{cm}^{-2}$ was used. In the future, this quantity should be correlated with cell voltage, flow rate, and other relevant operating parameters.

\section{Mechanical Energy Requirement}

The mechanical energy balance for an incompressible fluid is given as Equation 20 [41-43]:

$$
\frac{\Delta u_{b}^{2}}{2 g_{c}}+\frac{g}{g_{c}} \Delta z+\frac{\Delta p}{\rho}+l w_{f}+\eta_{p} W_{s}=0
$$

where $u_{b}$ is the change in average velocity of the electrolyte in the open channel between pairs of CAC electrodes, $g$ is the gravitational acceleration, $g_{c}$ is the gravitational constant, $z$ is the elevation, $p$ is the pressure, $\rho$ is the electrolyte density, and $l w_{f}$ is the lost work due to friction. The lost work due to friction, based upon the Fanning friction factor, is:

$$
l w_{f}=\frac{2 f^{*} L u_{b}^{2}}{g_{c} D}
$$

The Fanning friction factor is defined as:

$$
f^{*}=\frac{g_{c} D(-\Delta p)}{2 u_{b}^{2} \rho L}
$$

Alternatively, the lost work due to friction, based upon the Moody friction factor, is: 


$$
l w_{f}=\frac{f L u_{b}^{2}}{2 g_{c} D}
$$

The Moody friction factor is defined as:

$$
f=\frac{2 g_{c} D(-\Delta p)}{u_{b}^{2} \rho L}
$$

Early work done with pipes indicates that [41]:

$$
f=\frac{64}{\operatorname{Re}}
$$

The Reynolds number is defined as:

$$
\operatorname{Re}=\frac{D_{e} u_{b} \rho}{g_{c} \mu}
$$

where $\mu$ is the viscosity and $D_{e}$ is the equivalent diameter, defined as four times (4X) the hydraulic radius, $r_{h}$. The hydraulic radius is defined as the cross-sectional area of the channel divided by the wetted perimeter:

$r_{h}=\frac{w \times h}{2(w+h)}$

The electrode width and separation are $w$ and $h$, respectively. A regression analysis of the data in Table 3 indicates that the Moody friction factor for a stack of 150 double-sided carbon aerogel electrodes is:

$$
f=\frac{14.3766}{\operatorname{Re}^{0.72917}}
$$

The $y$ variance was 0.206 , the $x-y$ variance was 0.011 , and the regression coefficient was 0.953 , all indicating a good fit to the data. The regression equation is compared to the actual data in Figure 7. Note that the sheets of carbon aerogel were 4 in $\times 8$ in $\times 0.010$ in $(10.2 \mathrm{~cm} \times 20.3 \mathrm{~cm} \mathrm{x}$ $0.025 \mathrm{~cm}$ ); the epoxy film used to glue the carbon aerogel to the titanium substrate was approximately 0.0025 in $(0.0064 \mathrm{~cm})$ thick; and the gaskets used to separate the titanium plates were 0.062 in $(0.16 \mathrm{~cm})$ thick without compression and about 0.052 in $(0.13 \mathrm{~cm})$ thick with compression. The gap separating adjacent sheets of carbon aerogel were approximately 0.027 in $(0.069 \mathrm{~cm})$. The corresponding hydraulic radius was 0.0143 in $(0.0363 \mathrm{~cm})$ and the equivalent diameter was 0.0536 in $(0.136 \mathrm{~cm})$. Contributions of the mechanical work for pumping to the total energy requirement of carbon aerogel CDI is summarized in Tables 2 and 3. 


\section{Results of Energy Analysis}

Theoretical Minimum. As previously discussed, the minimum theoretical work required by an isothermal process to separate $\mathrm{SW}(\sim 35,000 \mathrm{ppm} \mathrm{NaCl})$ or $\mathrm{BW}(\sim 1600 \mathrm{ppm} \mathrm{NaCl})$ into a $10 \mathrm{ppm}$ stream and saturated brine has been calculated. This calculation requires that the activity coefficient of $\mathrm{NaCl}$ be estimated with the Debye-Huckel Theory. The estimated minimum work requirements for desalination of $35,000 \mathrm{ppm}$ and $1600 \mathrm{ppm} \mathrm{NaCl}$ solutions are $4.2 \mathrm{Wh} \mathrm{gal}^{-1}$ $\left(4.0 \mathrm{~kJ} \mathrm{~L}^{-1}\right)$ and $\sim 0.37 \mathrm{Wh} \mathrm{gal}^{-1}\left(0.35 \mathrm{~kJ} \mathrm{~L}^{-1}\right)$, respectively.

Comparison of Technologies for Desalination. Competiting technologies for SW desalination include reverse osmosis (RO), mechanical vapor recompression (MVC), electrodialysis (ED), multistage flash (MSF), multiple effect distillation with mechanical vapor recompression (MEDMVC) and multiple effect distillation with thermal vapor recompression (MED-TVC). Published data indicates that RO consumes $\sim 25-36 \mathrm{Wh} \mathrm{gal}^{-1}\left(24-34 \mathrm{~kJ} \mathrm{~L}^{-1}\right)$, MVC consumes $\sim 30$ $41 \mathrm{Wh} \mathrm{gal}^{-1}$ (29-39 kJ L $\mathrm{kJ}^{-1}$, ED consumes $\sim 60-75 \mathrm{Wh} \mathrm{gal}^{-1}\left(57-71 \mathrm{~kJ} \mathrm{~L}^{-1}\right)$, MED-TVC consumes 215-315 Wh gal $\mathrm{Wh}^{-1}$ (205-300 kJ L ${ }^{-1}$ ), MSF consumes $\sim 320 \mathrm{Wh} \mathrm{gal}^{-1}$ (304 kJ L $)$, and simple evaporation without energy recovery consumes $\sim 2720 \mathrm{Wh} \mathrm{gal}^{-1}\left(2586 \mathrm{~kJ} \mathrm{~L}^{-1}\right)$. The estimated energy requirement for SW desalination with carbon aerogel CDI is $\sim 18-27 \mathrm{Wh} \mathrm{gal}^{-1}(17-26 \mathrm{~kJ}$ $\mathrm{L}^{-1}$ ), depending upon cell voltage, flow rate, and energy recovery. The primary competiting technologies for $\mathrm{BW}$ desalination are electrodialysis (ED) and reverse osmosis (RO). Published data for the desalination of $1600 \mathrm{ppm} \mathrm{BW}$ indicates that RO consumes $\sim 5.3-8.5 \mathrm{Wh} \mathrm{gal}^{-1}(5.0-8.1$ $\left.\mathrm{kJ} \mathrm{L}^{-1}\right)$, while $\mathrm{ED}$ consumes $\sim 7.7 \mathrm{Wh} \mathrm{gal}^{-1}\left(7.3 \mathrm{~kJ} \mathrm{~L}^{-1}\right)$. The estimated energy requirement for desalination of such BW with carbon aerogel CDI is $\sim 1.2-2.5 \mathrm{Wh} \mathrm{gal}^{-1}\left(1.1-2.4 \mathrm{~kJ} \mathrm{~L}^{-1}\right)$, depending upon cell voltage, flow rate, and energy recovery. The energy requirements for each of these technologies, applied to SW desalination, is compared in Figure 8. Similarly, the energy requirements for $\mathrm{BW}$ applications of $\mathrm{RO}, \mathrm{ED}$, and carbon aerogel CDI are compared in Figure 9.

Other Observations. From the analysis presented in Tables 2 and 3, it is evident that the openchannel cell design used in carbon aerogel CDI minimizes the mechanical energy required for pumping to a level where energy requirements are dominated by the stored electrical energy and the energy consumed by parasitic electrochemical reactions such as oxygen reduction. Note that the cell design also minimizes ohmic losses to a very low level. Clearly, efforts to improve process efficiency should be directed towards the elimination or avoidance of parasitic cell current. It is believed that this can be done through stripping, catalytic surfaces that eliminate reactants upstream, the use of suitable electrode poisons (inhibitors), or other conductive aerogels with greater activation overpotentials for oxygen reduction and other relevant reactions. Additional work needs to be done to quantitatively determine parasitic current as a function of all relevant operating parameters.

\section{Discussion}

Scale Formation. Most of the salts found in SW and BW have inverted solubilities, which means that their solubilities decrease with increasing temperature. Thus, precipitation and scaleformation problems encountered at heat transfer surfaces in thermal desalination processes such 
as MED-TVC, MED-MVC and MSF become worse as operating temperatures are increased. Furthermore, the thermal decomposition of carbonates such as $\mathrm{CaCO}_{3}$ produces $\mathrm{CO}_{2}$ and scaleforming hydroxides. Such scale formation can be mitigated by suppressing the $\mathrm{pH}$ with $\mathrm{HCl}$ or $\mathrm{H}_{2} \mathrm{SO}_{4}$ additions to the feed. Unfortunately, such acid dosing accelerates corrosion and can contribute to scale formation through the formation of $\mathrm{CaSO}_{4}$, which is also relatively insoluble. By using ion exchange columns to remove scale-forming solutes such as $\mathrm{Ca}^{2+}, \mathrm{Mg}^{2+}$ and $\mathrm{SO}_{4}{ }^{2-}$ (hardness) from $\mathrm{SW}$ and $\mathrm{BW}$, a relativley soft $\mathrm{NaCl}$ solution is obtaned. This softened stream can then be fed to the evaporator of a thermal desalination process with substantially less risk of scale formation. This strategy has been explored by Donath [44]. RO and ED are also susceptible to scale-formation. As previously discussed, concentration polarization at the brinemembrane interface in a RO system can result in localized supersaturation, precipitation and scale formation. Here too chemicals are added to the feed to help minimize scale formation problems. The ion separation inherent in carbon aerogel CDI results in the formation of highsolubility acids and bases at anodes and cathodes, respectively, during regeneration (discharge). Thus, scale formation due to precipitation from supersaturated solution at the electrodeelectrolyte interface is avoided.

Other Operational Advantages of Carbon Aerogel CDI. Compressor maintenance and repair required by MVC and MED-MVC are avoided. Since no membranes or high pressure pumps are needed, carbon aerogel CDI also offers operational advantages over RO and ED. Conventional $\mathrm{RO}$ plants require differential pressures of $\sim 400-600$ psi (27-41 atm) across membranes for BW desalination, and differential pressures of $\sim 1000-1500 \mathrm{psi}$ (68-102 atm) for SW desalination. RO plants with new advanced membrane technology and no fouling may be able to operate at lower initial pressures, perhaps as low as $200 \mathrm{psi}(14 \mathrm{~atm})$ in the case of BW desalination. However, the pressure drop across a carbon aerogel CDI system used for BW desalination is expected to be far less (Table 3). Typically, the shelf life of RO membranes is 3 to 5 years, requiring cold storage during that period of time. Carbon aerogel electrodes have an indefinite shelf life and require no cold storage. Furthermore, RO membranes are susceptible to many of the chemicals used for water treatment. Note that polyamide has been found to be sensitive to attack by chlorine, whereas carbon aerogel is believed to be relatively resistant. The cost of replacing damaged membranes is high. In the case of early RO systems, approximately $52 \%$ of the cost of purified water was due to membrane replacements [43]. The cost of membrane raplacements in modern systems is still high, accounting for approximately $32 \%$ of the cost of purified water [4]. These costs will be greater if more expensive membranes are used.

Recent Improvements in RO Technology. Recent improvements in RO technology may lead to improved energy efficiency [47]. The cost of desalinating 1000 gallons of oceanic SW ( 35,000 ppm) with $\mathrm{RO}$ is given as $\$ 3.34$ by Shield and Moch. In their computational analysis, approximately $40 \%$ of that cost appears to be due to the required electrical power. Since they assume that electrical power costs approximately $\$ 0.08$ per $\mathrm{kW}$, the corresponding electrical power requirement must have been 17-18 $\mathrm{Wh} \mathrm{gal}^{-1}\left(16-17 \mathrm{~kJ} \mathrm{~L}^{-1}\right)$. No figures for $\mathrm{BW}$ desalination are given. 
Remediation of Contaminated Ground Water. Ion exchange is now used to remove heavy metals from contaminated ground water. Unfortunately, the chemical regeneration of saturated ion exchange resin produces a significant amount of secondary waste. A variety of electrochemical alternatives to ion exchange are now under investigation. For example, polypyrolle films on reticulated vitreous carbon electrodes are being used for in situ reduction of $\mathrm{Cr}$ (VI) [45]. This approach appears to suffer from a gradual degradation of the electrodes due to a loss of polypyrolle. Another process involves the use of electrodes coated with films of electroactive ferrocyanide for selective removal $\mathrm{Cs}^{+}$from solutions of sodium salts [46]. Here too electrode life may be limited by the stability of the electroactive film. Carbon aerogel electrodes appear to have the necessary selectivity and stability to enable them to serve as a viable alternative to ion exchange. Treatability tests at LLNL have shown that $35 \mathrm{ppm} \mathrm{Cr}(\mathrm{VI})$ can be selectively removed from contaminated ground water with a $530 \mathrm{ppm}$ TDS background [24,27]. Reversibility was demonstrated by quantitiative recovery of all electrosorbed chromium during regeneration. Carbon aerogel $\mathrm{CDI}$ has also been used to remove $\mathrm{Cu}, \mathrm{Zn}, \mathrm{Cd}, \mathrm{Pb}, \mathrm{Cr}, \mathrm{Mn}, \mathrm{Co}$ and $\mathrm{U}$ from process solutions and natural waters by electrosorption on CAC electrodes [24].

\section{Summary}

The minimum theoretical work required by an isothermal process to separate sea water $(\sim 35,000$ ppm $\mathrm{NaCl})$ or brackish water $(\sim 1600 \mathrm{ppm} \mathrm{NaCl})$ into a $10 \mathrm{ppm}$ stream and saturated brine has been calculated. This calculation requires that the activity coefficient of $\mathrm{NaCl}$ be estimated with the Debye-Huckel Theory. The estimated minimum work requirements for desalination of SW and $1600 \mathrm{ppm} \mathrm{BW}$ are $\sim 4.2 \mathrm{Wh} \mathrm{gal}^{-1}\left(4.0 \mathrm{~kJ} \mathrm{~L}^{-1}\right)$ and $\sim 0.37 \mathrm{Wh} \mathrm{gal}^{-1}\left(0.35 \mathrm{~kJ} \mathrm{~L}^{-1}\right)$, respectively. Data from several operating desalination processes were published by Wade in 1993 [2]. His work indicates that RO consumes $\sim 25-36 \mathrm{Wh} \mathrm{gal}^{-1}\left(24-34 \mathrm{~kJ} \mathrm{~L}^{-1}\right)$, MVC consumes $\sim 30-41 \mathrm{Wh}$ $\mathrm{gal}^{-1}$ (29-39 kJ L $)$, ED consumes $\sim 60-75 \mathrm{Wh} \mathrm{gal}^{-1}$ (57-71 kJ L'), MED-TVC consumes $\sim 215$ $315 \mathrm{Wh} \mathrm{gal}^{-1}\left(205-300 \mathrm{~kJ} \mathrm{~L}^{-1}\right)$, and MSF consumes $\sim 320 \mathrm{Wh} \mathrm{gal}^{-1}\left(304 \mathrm{~kJ} \mathrm{~L}^{-1}\right)$. Simple evaporation without energy recovery consumes $\sim 2720 \mathrm{Wh} \mathrm{gal}^{-1}\left(2587 \mathrm{~kJ} \mathrm{~L}^{-1}\right)$. More recent computational analysis by Shields and Moch assumes that $\mathrm{RO}$ requires $17-18 \mathrm{Wh} \mathrm{gal}^{-1}(16-17 \mathrm{~kJ}$ $\left.\mathrm{L}^{-1}\right)$. The primary competiting technologies for $\mathrm{BW}$ desalination are ED and RO [4]. Published data for the desalination of $1600 \mathrm{ppm} \mathrm{BW}$ indicates that RO consumes $~ 5.3-8.5 \mathrm{Wh}^{-1} \mathrm{gal}^{-1}(5.0-8.1$ $\left.\mathrm{kJ} \mathrm{L}^{-1}\right)$, while ED consumes $\sim 7.7 \mathrm{Wh} \mathrm{gal}^{-1}\left(7.3 \mathrm{~kJ} \mathrm{~L}^{-1}\right)$.

The estimated energy requirement for desalination of $35,000 \mathrm{ppm} \mathrm{SW}$ with carbon aerogel CDI is $\sim 18-27 \mathrm{Wh} \mathrm{gal}^{-1}\left(17-26 \mathrm{~kJ} \mathrm{~L}^{-1}\right)$, depending upon cell voltage, flow rate, and energy recovery. Based upon required energy, carbon aerogel CDI appears to be very competitive for this particular application. The estimated energy requirement for desalination of $1600 \mathrm{ppm} \mathrm{BW}$ is only $\sim 1.2-2.5 \mathrm{Wh} \mathrm{gal}^{-1}\left(1.1-2.4 \mathrm{~kJ} \mathrm{~L}^{-1}\right)$, though better results may be possible with optimization. Carbon aerogel CDI appears to be more competitive for $\mathrm{BW}$ desalination than for $\mathrm{SW}$ desalination. It also seems that many of the problems associated with the corrosion and scaling of heat transfer surfaces in thermal SW desalination processes such as MSF, MED-MVC and MED-TVC can be avoided through the use of this technology. Since no membranes or high pressure pumps are required, carbon aerogel CDI offers operational advantages over RO and ED. With additional investments in research and development, it may be possible to develop carbon 
aerogel CDI to a point where practical, large-scale desalination is possible. However, such applications will probably require significant reductions in the costs of materials.

Carbon aerogel electrodes have demonstrated the necessary selectivity and stability to enable them to serve as a viable alternative to ion exchange resins for the remediation of $\mathrm{Cr}(\mathrm{VI})$ contaminated ground water. Field tests at LLNL have shown that carbon aerogel electrodes can be used to selectively remove $35 \mathrm{ppb} \mathrm{Cr}(\mathrm{VI})$ from contaminated ground water with a $530 \mathrm{ppm}$ TDS background. Consequently, it may be possible to avoid the generation of large quantities of secondary waste, produced during chemical regeneration of ion exchange columns.

\section{Acknowledgment}

Contributions of R. W. Pekala are gratefully acknowledged. Funding for initial process development was provided by the Strategic Environmental Research and Development Program (SERDP). Funding and the opportunity to explore desalination applications has been provided by the Alameda County Water District in California. This work was done under the auspices of the U.S. Department of Energy (DOE) by Lawrence Livermore National Laboratory (LLNL) under Contract No. W-7405-Eng-48.

\section{References}

1. L. J. Summers, "Desalination Processes and Performance," Lawrence Livermore National Laboratory, UCRL-ID-120367, June 14 (1995).

2. N. M. Wade, "Technical and Economic Evaluation of Distillation and Reverse Osmosis Desalination Processes," Desalination, Vol. 93, pp. 343-363, (1993).

3a. W. J. Conlon, "Membrane Processes," Chapt. 11, Water Quality and Treatment, A Handbook of Community Water Supplies, 4th Ed., R. W. Pontius, Ed., American Water Works Association, McGraw-Hill, San Francisco, CA, pp. $709-746$ (1990).

3b. R. M. Clark, "Water Supply," Chapt. 5, Standard Handbook of Environmental Engineering, R. A. Corbitt, Ed., McGraw-Hill, San Francisco, CA, pp. 5.146-149 (1989).

4. R. C. Harries, D. Elyanow, "Desalination of Brackish Groundwater for a Prarie Community Using Electrodialysis Reversal," Desalination, Vol. 84, pp. 109-121, (1991).

5. A. H. Khan, Desalination Processes and Multistage Flash Distillation Practice, Desalination and Water Purification, Vol. 1, Elsevier, New York, NY, pp. 124-137, 162-168, 570-586 (1986).

6. P. K. Narayanan, S. K. Thampy, N. J. Dave, D. K. Chauhan, B. S. Makwana, S. K. Adhikary, V. K. Indusekhar, "Performance of the First Sea Water Electrodialysis Desalination Plant in India," Desalination, Vol. 84, pp. 201-211, (1991). 
7. B. B. Arnold, G. W. Murphy, "Studies on the Electrochemistry of Carbon and Chemically Modified Carbon Surfaces," J. Phys. Chem., Vol. 65, No. 1, pp. 135-138 (1961).

8. D. D. Caudle, J. H. Tucker, J. L. Cooper, B. B. Arnold, A. Papastamataki, "Electrochemical Demineralization of Water with Carbon Electrodes," Research and Development Progress Report No. 188, United States Department of Interior, 190 pages, May (1966).

9. A. M. Johnson, A. W. Venolia, J. Newman, R. G. Wilbourne, C. M. Wong, , W. S. Gillam, S. Johnson, R. H. Horowitz, "Electrosorb Process for Desalting Water," Office of Saline Water Research and Development Progress Report No. 516, U.S. Dept. Interior Pub. 200 056, 31 pages, March (1970).

10. A. M. Johnson, A. W. Venölia, R. G. Wilbourne, J. Newman, "The Electrosorb Process for Desalting Water," Marquardt Co., Van Nuys, CA, 36 pages, March (1970).

11. A. M. Johnson, "Electric Demineralizing Apparatus," U.S. Pat. No. 3515664, June 2 (1970).

12. A. M. Johnson, J. Newman, "Desalting by Means of Porous Carbon Electrodes," J. Electrochem. Soc., Vol. 118, No. 3, pp. 510-517 (1971).

13. Y. Oren, A. Soffer, "Electrochemical Parametric Pumping," J. Electrochem. Soc., Vol. 125, No. 6, pp. 869-875 (1978).

14. Y. Oren, A. Soffer, "Water Desalting by Means of Electrochemical Parametric Pumping: I. The Equilibrium Properties of a Batch Unit Cell," J. Appl. Electrochem., Vol. 13, No. 4, pp. 473-487 (1983).

15. Y. Oren, A. Soffer, "Water Desalting by Means of Electrochemical Parametric Pumping: II. Separation Properties of a Multistage Column," J. Appl. Electrochem., Vol. 13, No. 4, pp. 489-505 (1983).

16. J. C. Farmer, "Method and Apparatus for Capacitive Deionization, Electrochemical Purification, and Regeneration of Electrodes," U.S. Pat. No. 5428858, June 20 (1995).

17. J. C. Farmer, D. V. Fix, G. V. Mack, R. W. Pekala, J. F. Poco, "The Use of Capacitive Deionization with Carbon Aerogel Electrodes to Remove Inorganic Contaminants from Water," Proc. 1995 Intl. Low-Level Conf., Orlando, Florida, July 10-12, 1995, Electric Power Research Institute, Palo Alto, CA, Rept. TR-105569, pp. 42 1-23 (1995).

18. J. C. Farmer, D. V. Fix, G. V. Mack, R. W. Pekala, J. F. Poco, "Capacitive Deionization of Water: An Innovative New Process," Proc. Fifth Intl. Conf. Rad. Waste Mgmt. Environ. Remediation, Berlin, Germany, September 3-9, 1995, American Society of Mechanical Engineers (ASME), New York, NY, Vol. 2, pp. 1215-1220 (1995). 
19. J. C. Farmer, D. V. Fix, G. V. Mack, R. W. Pekala, J. F. Poco, "Capacitive Deionization with Carbon Aerogel Electrodes: Carbonate, Sulfate, and Phosphate," Proc. 1995 Intl. SAMPE Tech. Conf., Albuquerque, NM, October 9-12, 1995, Society for the Advancement of Material and Process Engineering (SAMPE), Covina, CA, Vol. 27, pp. 294-304 (1995).

20. J. C. Farmer, D. V. Fix, G. V. Mack, R. W. Pekala, J. F. Poco, "Capacitive Deionization of $\mathrm{NaCl}$ and $\mathrm{NaNO}_{3}$ Solutions with Carbon Aerogel Electrodes," J. Electrochem. Soc., Vol. 143, No. 1, pp. 159-169 (1996).

21. J. C. Farmer, D. V. Fix, G. V. Mack, R. W. Pekala, J. F. Poco, "Capacitive Deionization of $\mathrm{NH}_{4} \mathrm{ClO}_{4}$ Solutions with Carbon Aerogel Electrodes," J. Appl. Electrochem., Vol. 26 (Ms. No. NA-025-95, in press) (1996).

22. J. C. Farmer, D. V. Fix, R. W. Pekala, J. K. Nielsen, A. M. Volpe, D. D. Dietrich, "The Use of Carbon Aerogel Electrodes for Environmental Cleanup," Proc. Symposium on the Production and Use of Carbon-Based Materials for Environental Cleanup, 1996 Spring Meeting of the American Chemical Society, New Orleans, Louisiana, March 24-29, 1996, Vol. 41, p. 484 (1996).

23. J. C. Farmer, R. W. Pekala, F. T. Wang, D. V. Fix, A. M. Volpe, D. D. Dietrich, W. H. Siegel, "Electrochemical and Photochemical Treatment of Aqueous Waste Streams," Proc. Spectrum 96, Nucl. Haz. Waste Mgmt. Intl. Topical, , Seattle, Washington, August 18-23, 1996, Am. Nucl. Soc., La Grange Park, IL (1996).

24. J. C. Farmer, G. V. Mack, D. V. Fix, "The Use of Carbon Aerogel Electrodes for Deionizing Water and Treating Aqueous Process Wastes," U. Calif., Lawrence Livermore Natl. Lab. Rept. UCRL-JC-123461 (1996); Intl. J. Environ. Conscious Des. Mfg., Vol. 6, No. 1, in press (1997).

25. A. J. Bard, L. R. Faulkner, "Double-Layer Structure and Adsorbed Intermediates in Electrode Processes," Chapt. 12, Electrochemical Methods. Fundamentals and Applications, John Wiley and Sons, New York, NY, pp. 488-552 (1980).

26. J. S. Newman, "Structure of the Electric Double Layer," Chapt. 7, Electrochemical Systems, 2nd Ed., Prentice Hall, Englewood Cliffs, NJ, pp. 157-185 (1991).

27. J. C. Farmer, S. M. Bahowick, J. E. Harrar, D. V. Fix, R. E. Martinelli, A. K. Vu, K. L. Carroll, "Electrosorption of Chromium Ions on Carbon Aerogel Electrodes as a Means of Remediating Ground Water," U. Calif., Lawrence Livermore Natl. Lab. Rept. UCRL-JC124565 Rev. 1, August 29 (1996); submitted for publication in special issue of Energy and Fuels (1997).

28. J. A. Trainham, J. Newman, "Flow-Through Porous Electrode Model: Application to Metal-Ion Removal from Dilute Streams," J. Electrochem. Soc., Vol. 124, No. 10, pp. 1528-1540 (1977). 
29. Van Zee, J. Newman, "Electrochemical Removal of Silver Ions from Photographic Fixing Solutions Using a Porous Flow-Through Electrode," J. Electrochem. Soc., Vol. 124, No. 5, pp. $706-708$ (1977).

30. M. Matlosz, J. Newman, "Experimental Investigation of a Porous Carbon Electrode for the Removal of Mercury from Contaminated Brine," J. Electrochem. Soc., Vol. 133, No. 9, pp. 1850-1859 (1986).

31. D. Pletcher, "Industrial Electrochemistry," Chapter 11, Water Treatment and Environmental Protection. Chapman and Hall, London, UK, p. 291 (1982).

32. Y. Hanzawa, K. Kaneko, R. W. Pekala, M. S. Dresselhaus, "Activated Carbon Aerogels," unpublished manuscript (1996).

33. R. W. Pekala, S. T. Mayer, J. F. Poco, J. L. Kaschmitter, "Structure and Performance of Carbon Aerogel Electrodes," in Novel Forms of Carbon II, C. L. Renschler, D. M. Cox, J. J. Pouch, Y. Achiba, Eds., MRS Symp. Proc., Vol. 349, No. 79 (1994).

34. J. Wang et al., "Carbon Aerogel Composite Electrodes,” Anal. Chem., Vol. 65, pp. 23002303 (1993).

35. R. W. Pekala, C. T. Alviso, in Novel Forms of Carbon, C. L. Renschler, J. J. Pouch, D. M. Cox, Eds., MRS Symp. Proc., Vol. 270, No. 3 (1992).

36. R. W. Pekala, in Ultrastructure Processing of Advanced Materials, D. R. Uhlmanjn, D. R. Ulrich, Eds., John Wiley and Sons, Inc., New York, NY, pp. 711-717 (1992).

37. S. T. Mayer, R. W. Pekala, J. L. Kaschmitter, "The Aerocapacitor: An Electrochemical Double-layer Energy-Storage Device," J. Electrochemical Society, Vol. 140, No. 2, pp. 446-451 (1993).

38. G. V. Mack, J. C. Farmer, D. V. Fix, G. W. Johnson, D. W. O'Brien, "Design of the Control System for the Continuous-Flow Potential-Swing Capacitive Deionization Process," U. Calif., Lawrence Livermore Natl. Lab. Rept. No. UCRL-ID-117626, September 30 (1994).

39. C. J. King, "Energy Requirements of Separation Processes," Chapt 13, Separation Processes, 2nd Ed., McGraw-Hill Chemical Engineering Series, McGraw-Hill, San Francisco, CA, pp. 660-727 (1980).

40. J. S. Newman, "Activity Coefficients," Chapt. 4, Electrochemical Systems, 2nd Ed., Prentice Hall, Englewood Cliffs, NJ, p. 86-115 (1991). 
41. C. O. Bennett, J. E. Myers, "The Overall Energy Balance," Chapt. 4, Momentum, Heat, and Mass Transfer, 2nd Ed., McGraw-Hill Chemical Engineering Series, McGraw-Hill, San Francisco, CA, pp. 40-60 (1974).

42. R. N. Robinson, "Flulid Statics and Dynamics," Chapt. 5, Chemical Engineering Reference Manual, 4th Ed., Professional Publications, Inc., Belmont, CA, pp. 5.1-5.38 (1987).

43. Chemical Engineers' Handbook, 5th Ed., R. H. Perry, C. H. Chilton, Ed., McGraw-Hill, San Francisco, CA (1973).

44. G. Donath, "Aufbereitung von Meerwasser Mit Ionenaustauschern," Vom Wasser, Vol. 61, pp. 237-238 (1983).

45. L. F. Fernandez, J. G. Ibanez, K. Rajeshwar, S. Basak, "The Reduction of Cr(VI) with Polypyrrole on Reticulated Vitreous Carbon: Miscellaneous Effects," 189th Mtg. Electrochem. Soc., Los Angeles, CA, May 5-10, 1996, Abs. 524, Ext. Abs., Vol. 96-1, p. 691.

46. M. Lilga, J. Sukamto, M. Buehler, "Electrically-Controlled Cesium Ion Exchange," Proc. 1996 Annual Technical Exchange Meeting, Efficient Separations and Processing Crosscutting Program, Gathersburg, MD, Jan. 16-19, 1996, pp. 47-52.

47. C. P. Shields, I. Moch, Jr., "Evaluation of Global Seawater Reverse Osmosis Capital and Operating Costs," Technical Paper, 17 pgs., ADA Conference, Monterey, California, August (1996). 
Table 1. Estimates of Total Energy Requirements for SW Desalination (Wade)

\begin{tabular}{|l|l|l|l|l|l|}
\hline Process & $\begin{array}{l}\text { Heat to } \\
\text { Process }\end{array}$ & $\begin{array}{l}\text { Heat to } \\
\text { Process }\end{array}$ & $\begin{array}{l}\text { Electrical } \\
\text { Power } \\
\text { Consumed }\end{array}$ & $\begin{array}{l}\text { Electrical } \\
\text { Power } \\
\text { Consumed }\end{array}$ & $\begin{array}{l}\text { Total } \\
\text { Required } \\
\text { Energy }\end{array}$ \\
\hline & $\mathbf{k J ~ k g ~}^{-1}$ & ${\text { Wh } \text { gal }^{-1}}^{-1}$ & $\mathbf{k W h ~}^{-3}$ & ${\text { Wh } \text { gal }^{-1}}^{-1}$ & Wh gal $^{-1}$ \\
\hline MSF & 290.6 & 305.6 & 3.9 & 14.8 & 320.3 \\
\hline MED+TVC & 290.6 & 305.6 & 2.7 & 10.2 & 315.8 \\
\hline MED+TVC & 193.8 & 203.8 & 2.9 & 11.0 & 214.8 \\
\hline MVC & & & 11.0 & 41.6 & 41.6 \\
\hline MVC & & & 8.0 & 30.3 & 30.3 \\
\hline RO+ERT & & & 6.5 & 24.6 & 24.6 \\
\hline RO & & & 9.5 & 36.0 & 36.0 \\
\hline
\end{tabular}


Table 2. Summary of Energy Requirements for Carbon Aerogel CDI Process.

\begin{tabular}{|c|c|c|c|c|c|c|c|c|}
\hline $\begin{array}{l}\text { Salt } \\
\text { Conc. }\end{array}$ & $\begin{array}{l}\text { Stacks in } \\
\text { Series }\end{array}$ & $\begin{array}{l}\text { Theoretical } \\
\text { Minimum } \\
\text { Energy }\end{array}$ & $\begin{array}{l}\text { Stored } \\
\text { Electrical } \\
\text { Energy }\end{array}$ & $\begin{array}{l}\text { Parasitic } \\
\text { Loss }\end{array}$ & $\begin{array}{l}\text { Ohmic } \\
\text { Loss }\end{array}$ & $\begin{array}{l}\text { Mechical } \\
\text { Work }\end{array}$ & $\begin{array}{l}\text { Total } \\
\text { Energy }\end{array}$ & $\begin{array}{l}\text { Energy } \\
\text { Ratio }\end{array}$ \\
\hline ppm & none & Wh gal $^{-1}$ & Wh gal $^{-1}$ & Wh gal ${ }^{-1}$ & Wh gal ${ }^{1}$ & Wh gal ${ }^{-1}$ & Wh gal ${ }^{-1}$ & none \\
\hline \multicolumn{9}{|l|}{ Case I } \\
\hline 100 & 1 & 0.03 & 0.10 & 0.18 & $2.58 \times 10^{-03}$ & $6.22 \times 10^{-03}$ & 0.22 & 7.16 \\
\hline 800 & 4 & 0.21 & 0.83 & 0.80 & $2.92 \times 10^{-03}$ & $2.81 \times 10^{-02}$ & 1.09 & 5.31 \\
\hline 1000 & 4 & 0.25 & 1.04 & 0.94 & $2.99 \times 10^{-03}$ & $3.30 \times 10^{-02}$ & 1.30 & 5.22 \\
\hline 3200 & 10 & 0.66 & 3.33 & 2.19 & $3.44 \times 10^{-03}$ & $7.67 \times 10^{-02}$ & 3.30 & 5.02 \\
\hline 10000 & 23 & 1.63 & 10.42 & 5.00 & $4.10 \times 10^{-03}$ & $1.75 \times 10^{-01}$ & 8.38 & 5.14 \\
\hline 20000 & 39 & 2.76 & 20.83 & 8.26 & $4.63 \times 10^{-03}$ & $2.90 \times 10^{-01}$ & 14.9 & 5.41 \\
\hline 30000 & 52 & 3.74 & 31.25 & 11.09 & $5.00 \times 10^{-103}$ & $3.89 \times 10^{-01}$ & 21.0 & 5.62 \\
\hline 35000 & 58 & 4.18 & 36.45 & 12.40 & $5.15 \times 10^{-05}$ & $4.35 \times 10^{-01}$ & 24.0 & 5.73 \\
\hline \multicolumn{9}{|l|}{ Case 2 } \\
\hline 100 & 0 & 0.03 & 0.10 & 0.12 & $2.76 \times 10^{-03}$ & $1.81 \times 10^{-04}$ & 0.15 & 5.04 \\
\hline 800 & 1 & 0.21 & 0.83 & 0.54 & $3.45 \times 10^{-03}$ & $8.20 \times 10^{-64}$ & 0.80 & 3.88 \\
\hline 1000 & 1 & 0.25 & 1.04 & 0.64 & $3.56 \times 10^{-03}$ & $9.64 \times 10^{-04}$ & 0.96 & 3.83 \\
\hline 3200 & 2 & 0.66 & 3.33 & 1.49 & $4.29 \times 10^{-05}$ & $2.24 \times 10^{-05}$ & 2.50 & 3.79 \\
\hline 10000 & 4 & 1.63 & 10.42 & 3.40 & $5.31 \times 10^{-03}$ & $5.12 \times 10^{-03}$ & 6.54 & 4.01 \\
\hline 20000 & 7 & 2.76 & 20.83 & 5.62 & $6.11 \times 10^{-03}$ & $8.46 \times 10^{-03}$ & 11.9 & 4.31 \\
\hline 30000 & 9 & 3.74 & 31.25 & 7.54 & $6.66 \times 10^{-035}$ & $1.14 \times 10^{-02}$ & 16.9 & 4.53 \\
\hline 35000 & 10 & 4.18 & 36.45 & 8.43 & $6.89 \times 10^{-105}$ & $1.27 \times 10^{-02}$ & 19.4 & 4.64 \\
\hline \multicolumn{9}{|l|}{ Case 3} \\
\hline 100 & 0 & 0.03 & 0.10 & 0.09 & $2.99 \times 10^{-03}$ & $1.76 \times 10^{-05}$ & 0.13 & 4.16 \\
\hline 800 & 0 & 0.21 & 0.83 & 0.42 & $3.97 \times 10^{-03}$ & $7.93 \times 10^{-05}$ & 0.68 & 3.28 \\
\hline 1000 & 0 & 0.25 & 1.04 & 0.50 & $4.12 \times 10^{-03}$ & $9.33 \times 10^{-05}$ & 0.81 & 3.25 \\
\hline 3200 & 1 & 0.66 & 3.33 & 1.15 & $5.09 \times 10^{-05}$ & $2.17 \times 10^{-644}$ & 2.16 & 3.28 \\
\hline 10000 & 1 & 1.63 & 10.42 & 2.63 & $6.42 \times 10^{-03}$ & $4.95 \times 10^{-144}$ & 5.77 & 3.54 \\
\hline 20000 & 2 & 2.76 & 20.83 & 4.36 & $7.47 \times 10^{-05}$ & $8.19 \times 10^{-044}$ & 10.6 & 3.85 \\
\hline 30000 & 3 & 3.74 & 31.25 & 5.84 & $8.18 \times 10^{-05}$ & $1.10 \times 10^{-53}$ & 15.2 & 4.07 \\
\hline 35000 & 3 & 4.18 & 36.45 & 6.54 & $8.48 \times 10^{-03}$ & $1.23 \times 10^{-155}$ & 17.5 & 4.18 \\
\hline \multicolumn{9}{|l|}{ Case 4} \\
\hline 100 & 0 & 0.03 & 0.05 & 0.30 & $3.37 \times 10^{-03}$ & $1.14 \times 10^{-04}$ & 0.32 & 10.53 \\
\hline 800 & 1 & 0.21 & 0.42 & 1.37 & $2.72 \times 10^{-03}$ & $5.16 \times 10^{-144}$ & 1.50 & 7.29 \\
\hline 1000 & 2 & 0.25 & 0.52 & 1.61 & $2.69 \times 10^{-03}$ & $6.07 \times 10^{-04}$ & 1.77 & 7.10 \\
\hline 3200 & 4 & 0.66 & 1.67 & 3.75 & $2.57 \times 10^{-135}$ & $1.41 \times 10^{-05}$ & 4.26 & 6.47 \\
\hline 10000 & 8 & 1.63 & 5.21 & 8.57 & $2.58 \times 10^{-03}$ & $3.22 \times 10^{-05}$ & 10.1 & 6.22 \\
\hline 20000 & 13 & 2.76 & 10.42 & 14.17 & $2.66 \times 10^{-03}$ & $5.33 \times 10^{-05}$ & 17.3 & 6.27 \\
\hline 30000 & 18 & 3.74 & 15.62 & 19.02 & $2.72 \times 10^{-05}$ & $7.15 \times 10^{-03}$ & 23.7 & 6.34 \\
\hline 35000 & 20 & 4.18 & 18.23 & 21.27 & $2.75 \times 10^{-05}$ & $8.00 \times 10^{-03}$ & 26.8 & 6.40 \\
\hline
\end{tabular}

Note: Cases 1 through 3 assume that the cell voltage is $1.2 \mathrm{~V}$. The flow rate through each 150electrode stack is assumed to be $1.59 \mathrm{gal} \mathrm{h}^{-1}\left(100 \mathrm{ml} \mathrm{min}^{-1}\right)$ in Case $1 ; 0.40 \mathrm{gal} \mathrm{h}^{-1}\left(25 \mathrm{ml} \mathrm{min}^{-1}\right)$ in Case 2; and $0.16 \mathrm{gal} \mathrm{h}^{-1}(10 \mathrm{ml} \mathrm{min}-1)$ in Case 3. Case 4 assumes a cell voltage of $0.6 \mathrm{~V}$ and a flow rate $0.40 \mathrm{gal} \mathrm{h}^{-1}\left(10 \mathrm{ml} \mathrm{min}^{-1}\right)$. The estimate of total energy requirement assumes $70 \%$ recovery of stored electrical energy and $70 \%$ pumping efficiency. 
Table 3. Mechanical Energy Balance on Carbon Aerogel CDI System.

\begin{tabular}{|c|c|c|c|c|c|c|c|c|c|}
\hline $\begin{array}{l}\text { Salt } \\
\text { Conc. }\end{array}$ & $\begin{array}{l}\text { Electro- } \\
\text { sorption } \\
\text { Capacity } \\
\text { (Anode) } \\
\end{array}$ & $\begin{array}{l}\text { Aerogel } \\
\text { Mass } \\
\text { Needed } \\
\text { (Anode) } \\
\end{array}$ & $\begin{array}{l}\text { Aerogel } \\
\text { Area } \\
\text { Needed } \\
\text { (Anode) }\end{array}$ & $\begin{array}{l}\text { No. 150- } \\
\text { Electrode } \\
\text { Stacks }\end{array}$ & $\begin{array}{l}\text { Flow } \\
\text { Rate }\end{array}$ & $\begin{array}{l}\text { Reynolds } \\
\text { Number }\end{array}$ & $\begin{array}{l}\text { Moody } \\
\text { Friction } \\
\text { Factor }\end{array}$ & $\overline{\Delta \mathbf{P}}$ & $\begin{array}{l}\text { Mech. } \\
\text { Work for } \\
\text { Pumping }\end{array}$ \\
\hline ppm & equiv $\mathrm{g}^{-1}$ & $1 b_{m}$ & $\mathrm{ft}^{2}$ & none & $\mathrm{ft}^{3} \mathrm{sec}^{-1}$ & none & none & psi & $\mathrm{Wh} \mathrm{gal}^{-\mathrm{T}}$ \\
\hline \multicolumn{10}{|l|}{ Case 1} \\
\hline 100 & $7.63 \times 10^{-05}$ & 0.593 & 27.6 & 1 & $5.89 \times 10^{-05}$ & 33.2 & 1.12 & 0.9 & $6.22 \times 10^{-03}$ \\
\hline 800 & $1.35 \times 10^{-04}$ & 2.68 & 125 & 4 & $5.89 \times 10^{-05}$ & 33.2 & 1.12 & 3.9 & $2.81 \times 10^{-02}$ \\
\hline 1000 & $1.44 \times 10^{-044}$ & 3.15 & 146 & 4 & $5.89 \times 10^{-05}$ & 33.2 & 1.12 & 4.5 & $3.30 \times 10^{-02}$ \\
\hline 3200 & $1.98 \times 10^{-04}$ & 7.31 & 340 & 10 & $5.89 \times 10^{-05}$ & 33.2 & 1.12 & 10.6 & $7.67 \times 10^{-02}$ \\
\hline 10000 & $2.71 \times 10^{-04}$ & 16.7 & 778 & 23 & $5.89 \times 10^{-05}$ & 33.2 & 1.12 & 24.1 & $1.75 \times 10^{-0 T}$ \\
\hline 20000 & $3.27 \times 10^{-04}$ & 27.6 & 1,290 & 39 & $5.89 \times 10^{-05}$ & 33.2 & 1.12 & 39.9 & $2.90 \times 10^{-0 T}$ \\
\hline 30000 & $3.66 \times 10^{-04}$ & 37.1 & 1,720 & 52 & $5.89 \times 10^{-05}$ & 33.2 & 1.12 & 53.5 & $3.89 \times 10^{-0 T}$ \\
\hline 35000 & $3.82 \times 10^{-04}$ & 41.5 & 1,930 & 58 & $5.89 \times 10^{-05}$ & 33.2 & 1.12 & 59.8 & $4.35 \times 10^{-0 T}$ \\
\hline \multicolumn{10}{|l|}{ Case 2} \\
\hline 100 & $1.12 \times 10^{-64}$ & 0.101 & 4.69 & $\leq 1$ & $1.47 \times 10^{-05}$ & 8.30 & 3.07 & 0.0 & $1.81 \times 10^{-04}$ \\
\hline 800 & $1.99 \times 10^{-04}$ & 0.455 & 21.2 & 1 & $1.47 \times 10^{-05}$ & 8.30 & 3.07 & 0.1 & $8.20 \times 10^{-04}$ \\
\hline 1000 & $2.11 \times 10^{-04}$ & 0.535 & 24.9 & 1 & $1.47 \times 10^{-05}$ & 8.30 & 3.07 & 0.1 & $9.64 \times 10^{-44}$ \\
\hline 3200 & $2.91 \times 10^{-04}$ & 1.24 & 57.9 & 2 & $1.47 \times 10^{-05}$ & 8.30 & 3.07 & 0.3 & $2.24 \times 10^{-03}$ \\
\hline 10000 & $3.98 \times 10^{-04}$ & 2.84 & 132 & 4 & $1.47 \times 10^{-15}$ & 8.30 & 3.07 & 0.7 & $5.12 \times 10^{-055}$ \\
\hline 20000 & $4.81 \times 10^{-124}$ & 4.70 & 219 & 7 & $1.47 \times 10^{-05}$ & 8.30 & 3.07 & 1.2 & $8.46 \times 10^{-03}$ \\
\hline 30000 & $5.38 \times 10^{-04}$ & 6.30 & 293 & 9 & $1.47 \times 10^{-05}$ & 8.30 & 3.07 & 1.6 & $1.14 \times 10^{-02}$ \\
\hline 35000 & $5.61 \times 10^{-04}$ & 7.05 & 328 & 10 & $1.47 \times 10^{-05}$ & 8.30 & 3.07 & 1.7 & $1.27 \times 10^{-02}$ \\
\hline \multicolumn{10}{|l|}{ Case 3} \\
\hline 100 & $1.45 \times 10^{-04}$ & 0.0312 & 1.45 & $\leq 1$ & $5.89 \times 10^{-06}$ & 3.32 & 6.00 & 0.0 & $1.76 \times 10^{-05}$ \\
\hline 800 & $2.56 \times 10^{-04}$ & 0.141 & 6.56 & $\leq 1$ & $5.89 \times 10^{-16}$ & 3.32 & 6.00 & 0.0 & $7.93 \times 10^{-105}$ \\
\hline 1000 & $2.73 \times 10^{-04}$ & 0.166 & 7.72 & $\leq 1$ & $5.89 \times 10^{-06}$ & 3.32 & 6.00 & 0.0 & $9.33 \times 10^{-05}$ \\
\hline 3200 & $3.75 \times 10^{-04}$ & 0.386 & 17.9 & 1 & $5.89 \times 10^{-06}$ & 3.32 & 6.00 & 0.0 & $2.17 \times 10^{-04}$ \\
\hline 10000 & $5.13 \times 10^{-04}$ & 0.881 & 41.0 & 1 & $5.89 \times 10^{-66}$ & 3.32 & 6.00 & 0.1 & $4.95 \times 10^{-104}$ \\
\hline 20000 & $6.21 \times 10^{-04}$ & 1.46 & 67.8 & 2 & $5.89 \times 10^{-26}$ & 3.32 & 6.00 & 0.1 & $8.19 \times 10^{-04}$ \\
\hline 30000 & $6.94 \times 10^{-04}$ & 1.95 & 90.9 & 3 & $5.89 \times 10^{-106}$ & 3.32 & 6.00 & 0.2 & $1.10 \times 10^{-05}$ \\
\hline 35000 & $7.24 \times 10^{-04}$ & 2.18 & 102 & 3 & $5.89 \times 10^{-06}$ & 3.32 & 6.00 & 0.2 & $1.23 \times 10^{-05}$ \\
\hline \multicolumn{10}{|l|}{ Case 4} \\
\hline 100 & $2.22 \times 10^{-05}$ & 0.203 & 9.46 & $\leq 1$ & $5.89 \times 10^{-66}$ & 3.32 & 6.00 & 0.0 & $1.14 \times 10^{-04}$ \\
\hline 800 & $3.94 \times 10^{-05}$ & 0.918 & 42.7 & 1 & $5.89 \times 10^{-66}$ & 3.32 & 6.00 & 0.1 & $5.16 \times 10^{-24}$ \\
\hline 1000 & $4.19 \times 10^{-05}$ & 1.08 & 50.2 & 2 & $5.89 \times 10^{-16}$ & 3.32 & 6.00 & 0.1 & $6.07 \times 10^{-04}$ \\
\hline 3200 & $5.77 \times 10^{-05}$ & 2.51 & 117 & 4 & $5.89 \times 10^{-06}$ & 3.32 & 6.00 & 0.2 & $1.41 \times 10^{-03}$ \\
\hline 10000 & $7.89 \times 10^{-05}$ & 5.73 & 267 & 8 & $5.89 \times 10^{-06}$ & 3.32 & 6.00 & 0.4 & $3.22 \times 10^{-05}$ \\
\hline 20000 & $9.54 \times 10^{-05}$ & 9.48 & 441 & 13 & $5.89 \times 10^{-06}$ & 3.32 & 6.00 & 0.7 & $5.33 \times 10^{-25}$ \\
\hline 30000 & $1.07 \times 10^{-04}$ & 12.7 & 592 & 18 & $5.89 \times 10^{-06}$ & 3.32 & 6.00 & 1.0 & $7.15 \times 10^{-05}$ \\
\hline 35000 & $1.11 \times 10^{-04}$ & 14.2 & 662 & 20 & $5.89 \times 10^{-16}$ & 3.32 & 6.00 & 1.1 & $8.00 \times 10^{-03}$ \\
\hline
\end{tabular}

Note: Cases 1 through 3 assume that the cell voltage is $1.2 \mathrm{~V}$. The flow rate through each 150 electrode stack is assumed to be $1.59 \mathrm{gal} \mathrm{h}^{-1}(100 \mathrm{ml} \mathrm{min})$ in Case $1 ; 0.40 \mathrm{gal} \mathrm{h}^{-1}\left(25 \mathrm{ml} \mathrm{min}^{-1}\right)$ in Case 2; and $0.16 \mathrm{gal} \mathrm{h}^{-1}(10 \mathrm{ml} \mathrm{min}-1)$ in Case 3. Case 4 assumes a cell voltage of $0.6 \mathrm{~V}$ and a flow rate $0.40 \mathrm{gal} \mathrm{h}^{-1}\left(10 \mathrm{ml} \mathrm{min}^{-1}\right)$. The estimate of total energy requirement assumes $70 \%$ recovery of stored electrical energy and $70 \%$ pumping efficiency. 


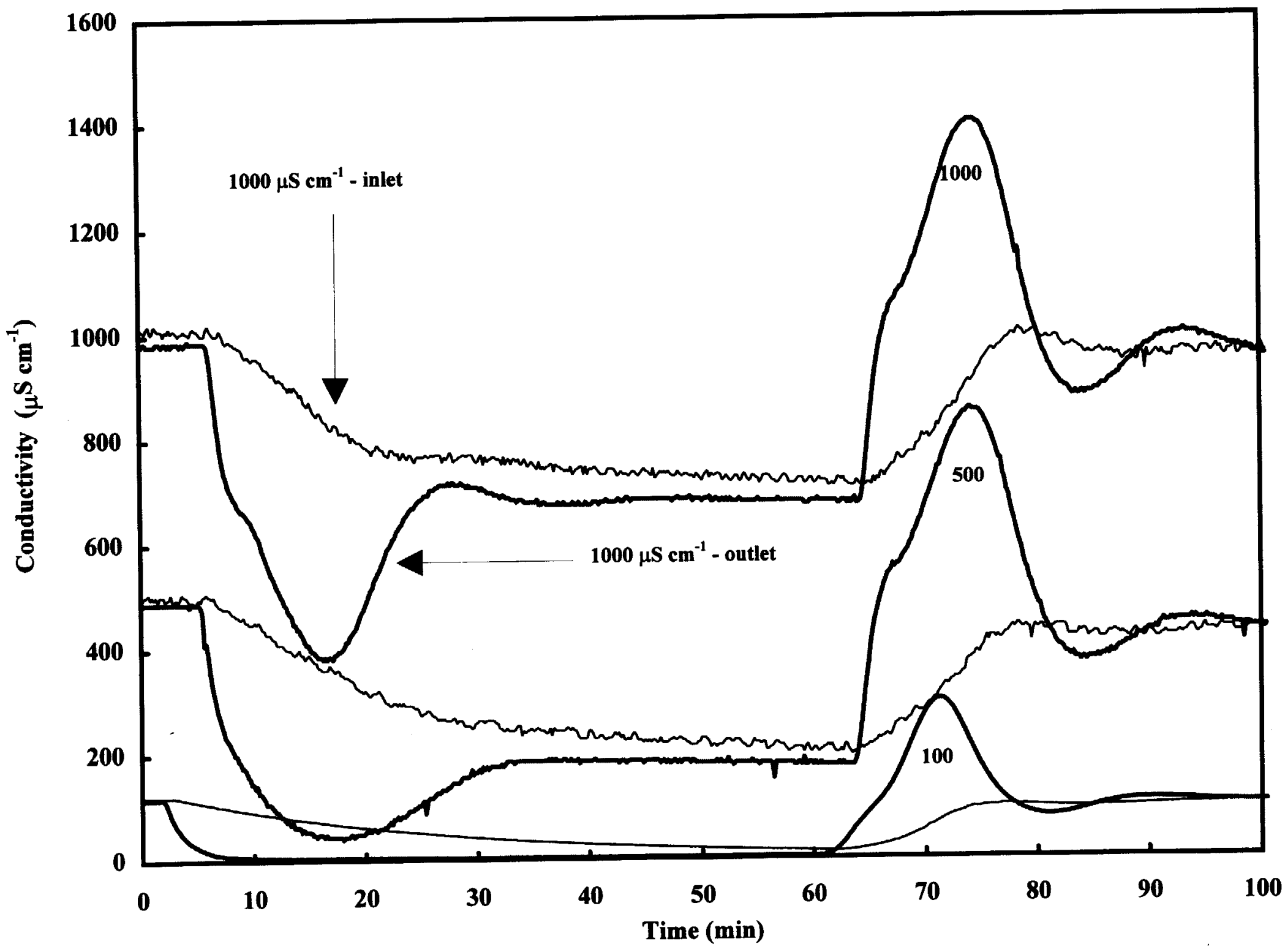

Figure 1. Electrosorption of $\mathrm{Na}^{+}$and $\mathrm{Cl}^{-}$ions on 54 double-sided $\mathrm{CAC}$ electrodes. Results for 100,500 and $1000 \mu \mathrm{S} \mathrm{cm}{ }^{-1}$. 


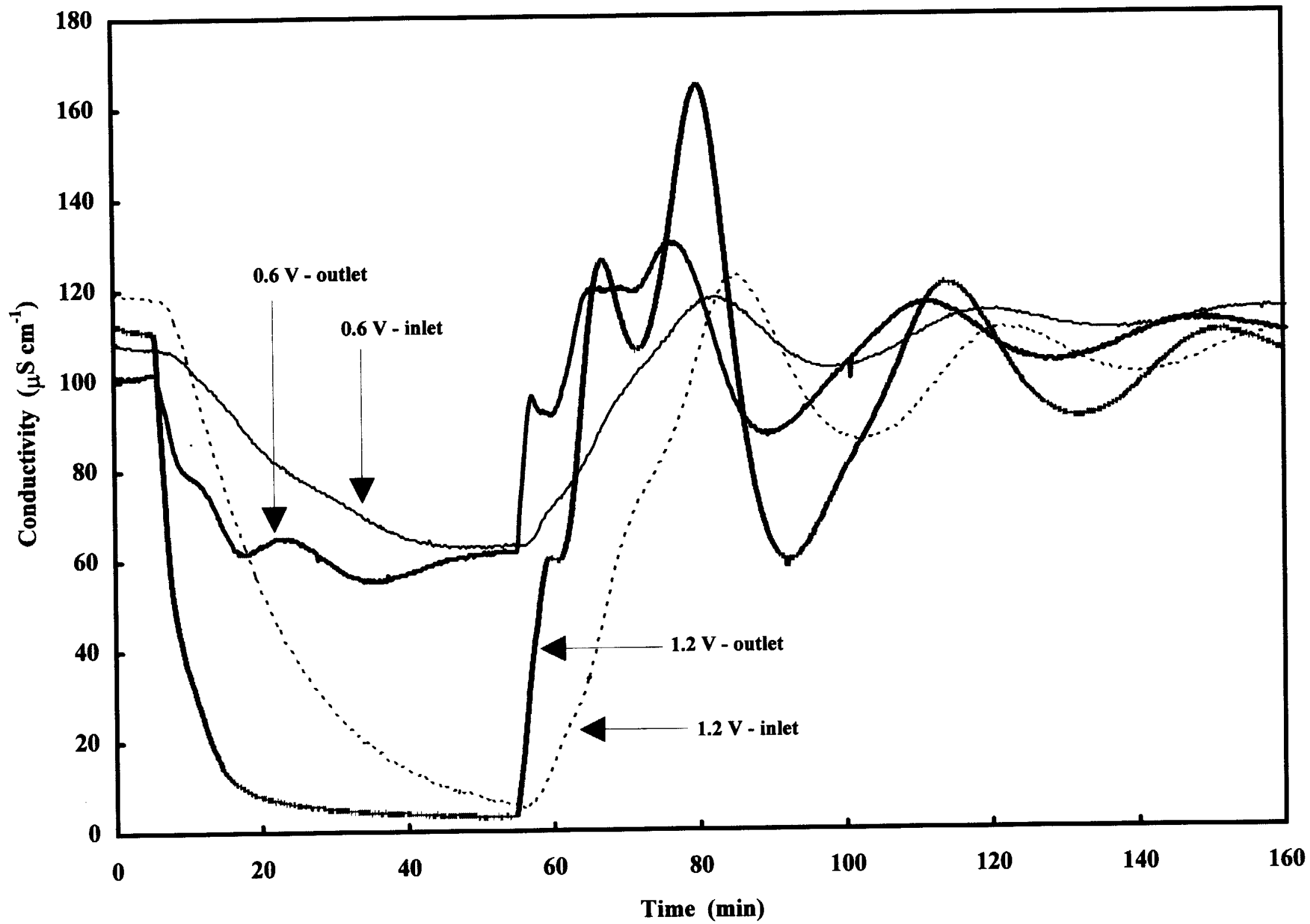

Figure 2. Electrosorption of $\mathrm{Na}+$ and $\mathrm{Cl}$ - on 100 double-sided CAC electrodes. Results for 0.6 and $1.2 \mathrm{~V}$ compared. 


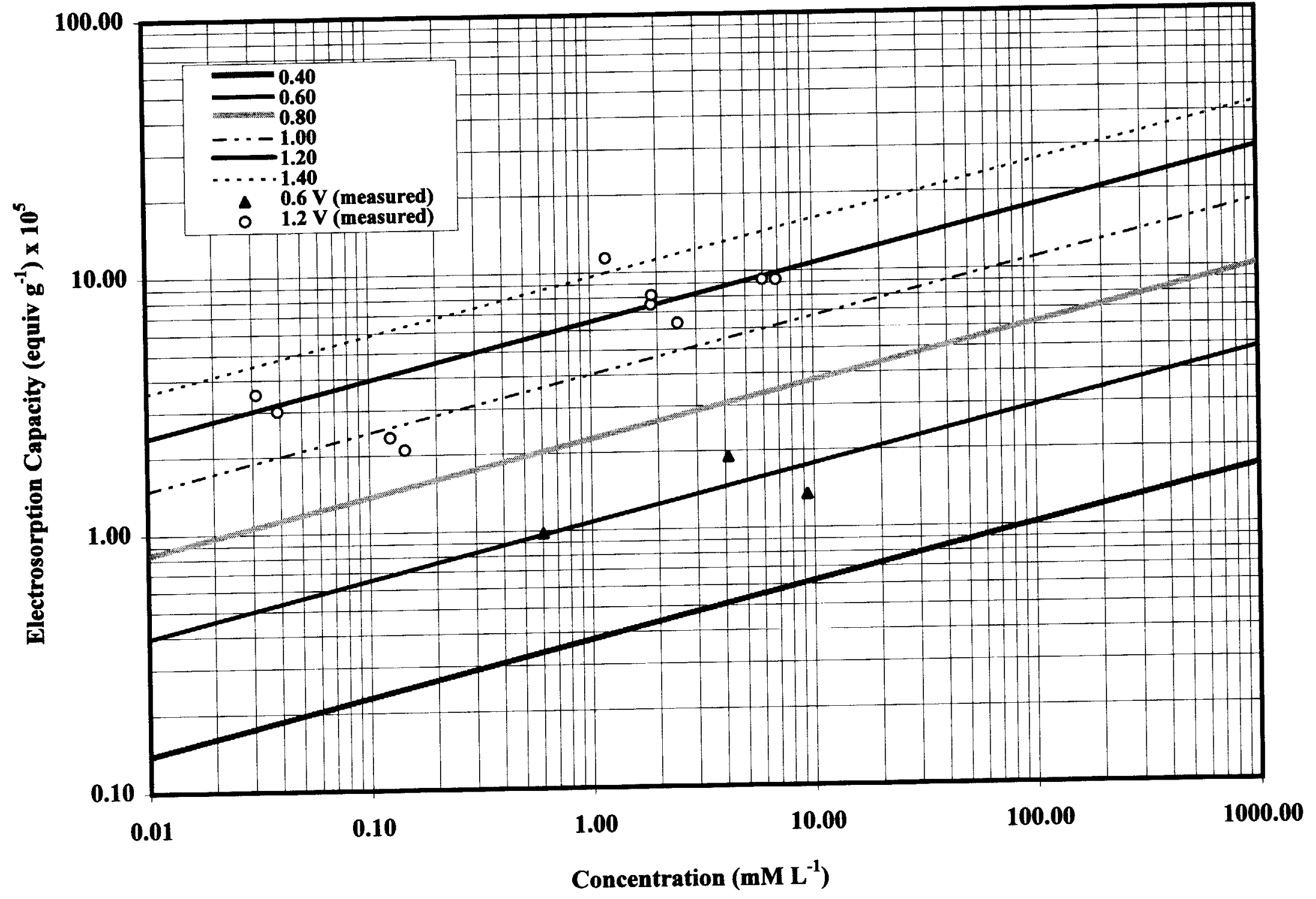

Figure 3. Electrosorption capacity for $\mathrm{NaCl}$ on carbon aerogel composite (CAC) electrodes. Comparison of first regression analysis (Equation 5) to experimental data. 


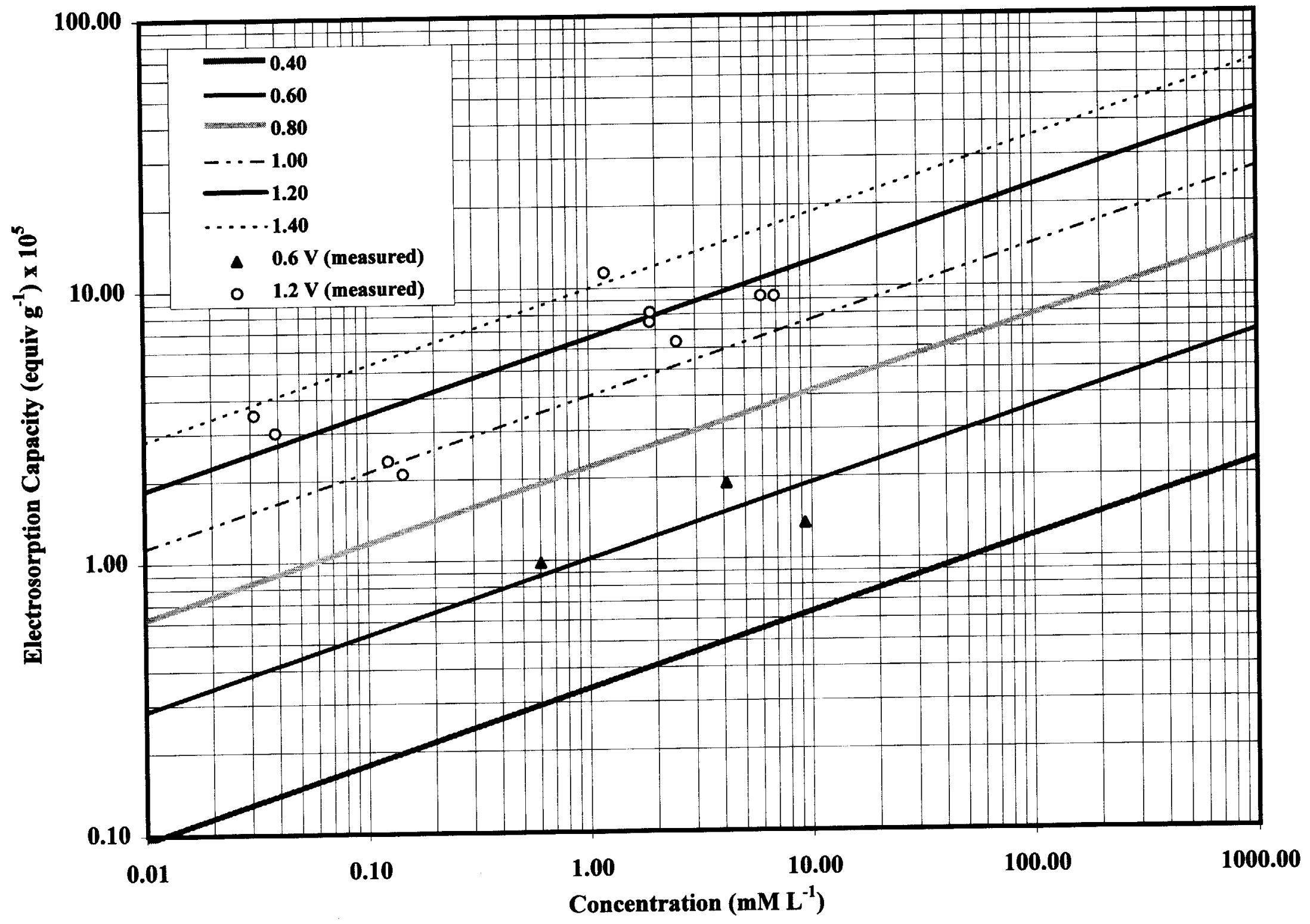

Figure 4. Electrosorption capacity for $\mathrm{NaCl}$ on carbon aerogel composite (CAC) electrodes. Comparison of second regression analysis (Equation 6) to experimental data. 


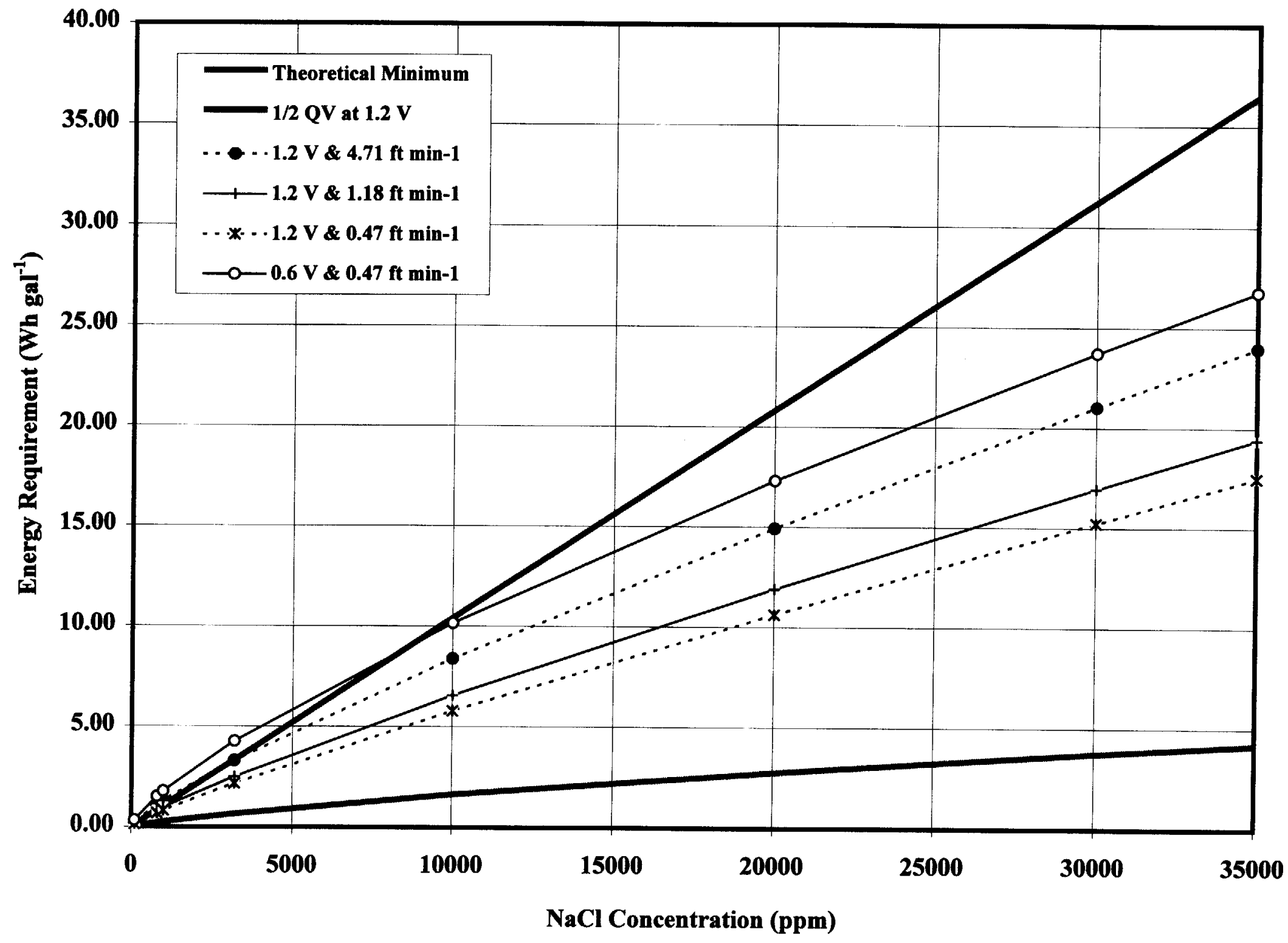

Figure 5. Estimates of the energy requirement for carbon aerogel composite $\mathrm{CDI}$ as a function of $\mathrm{NaCl}$ concentration (0-35,000 $\mathrm{ppm})$. 


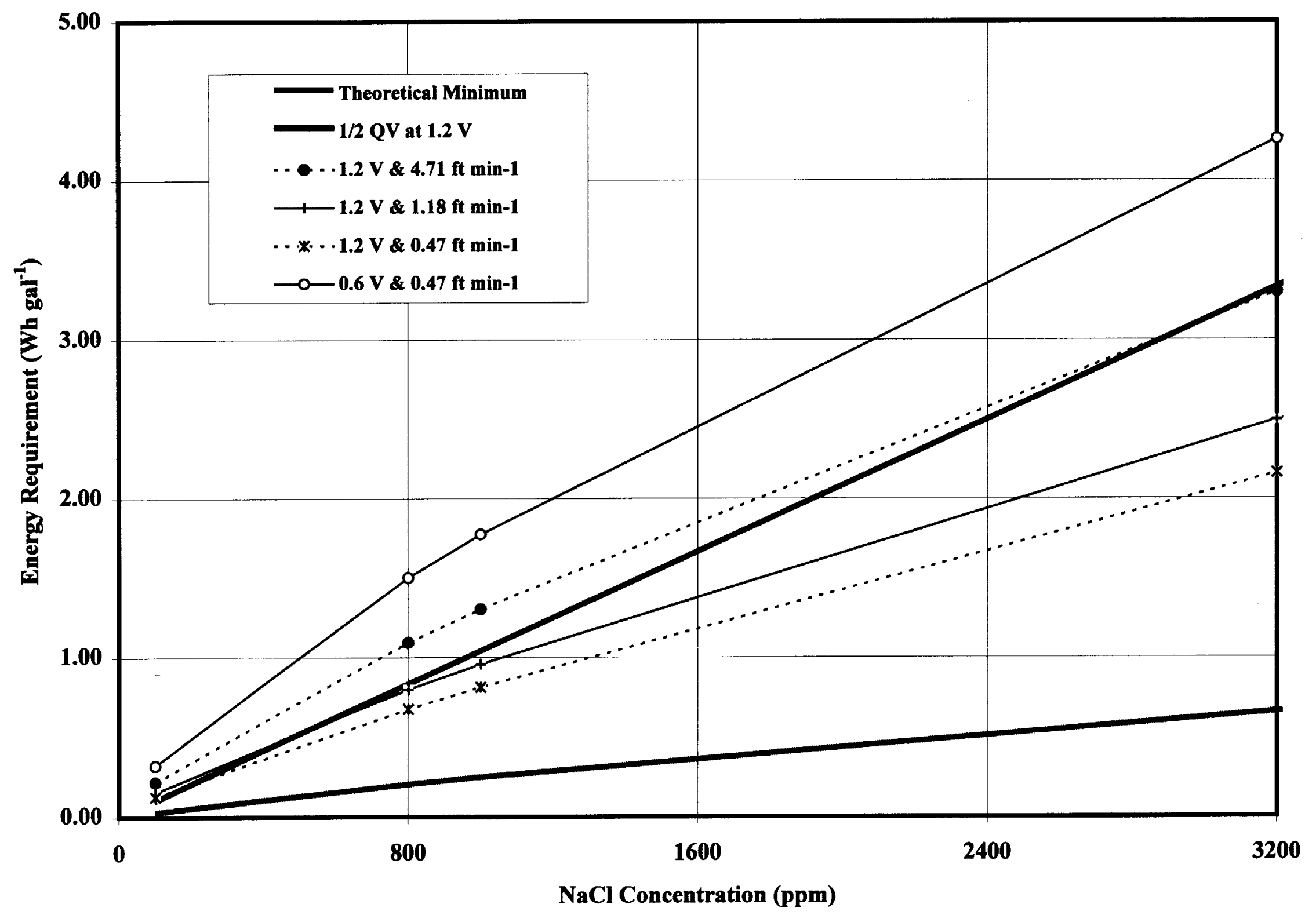

Figure 6. Estimates of the energy requirement for carbon aerogel $\mathrm{CDI}$ as a function of $\mathrm{NaCl}$ concentration (0-3200 $\mathrm{ppm})$. 


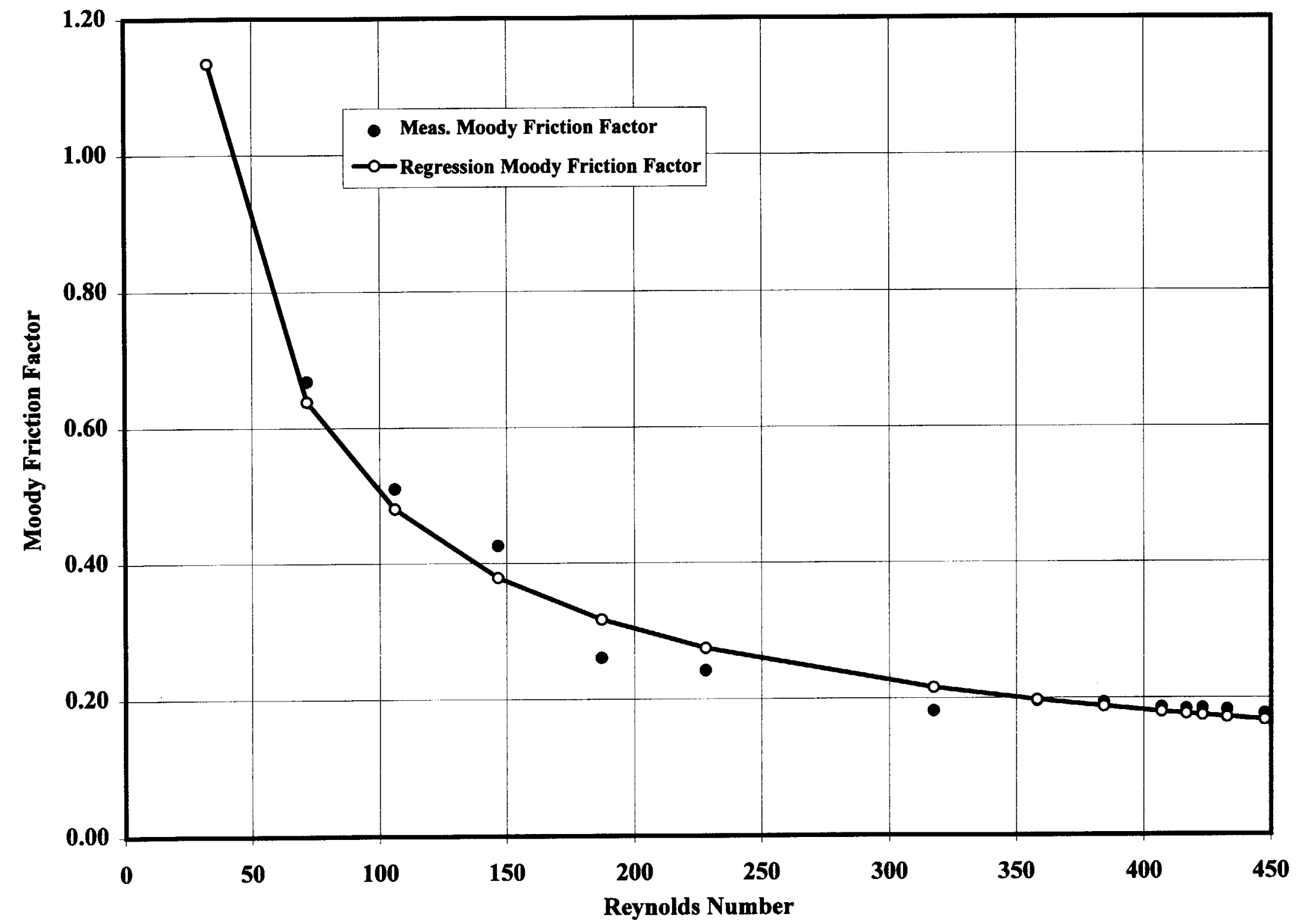

Figure 7. Moody friction factor, based upon measured pressure drop, correlated with Reynolds number. 
Energy Required (Wh gal ${ }^{-1}$ )

告

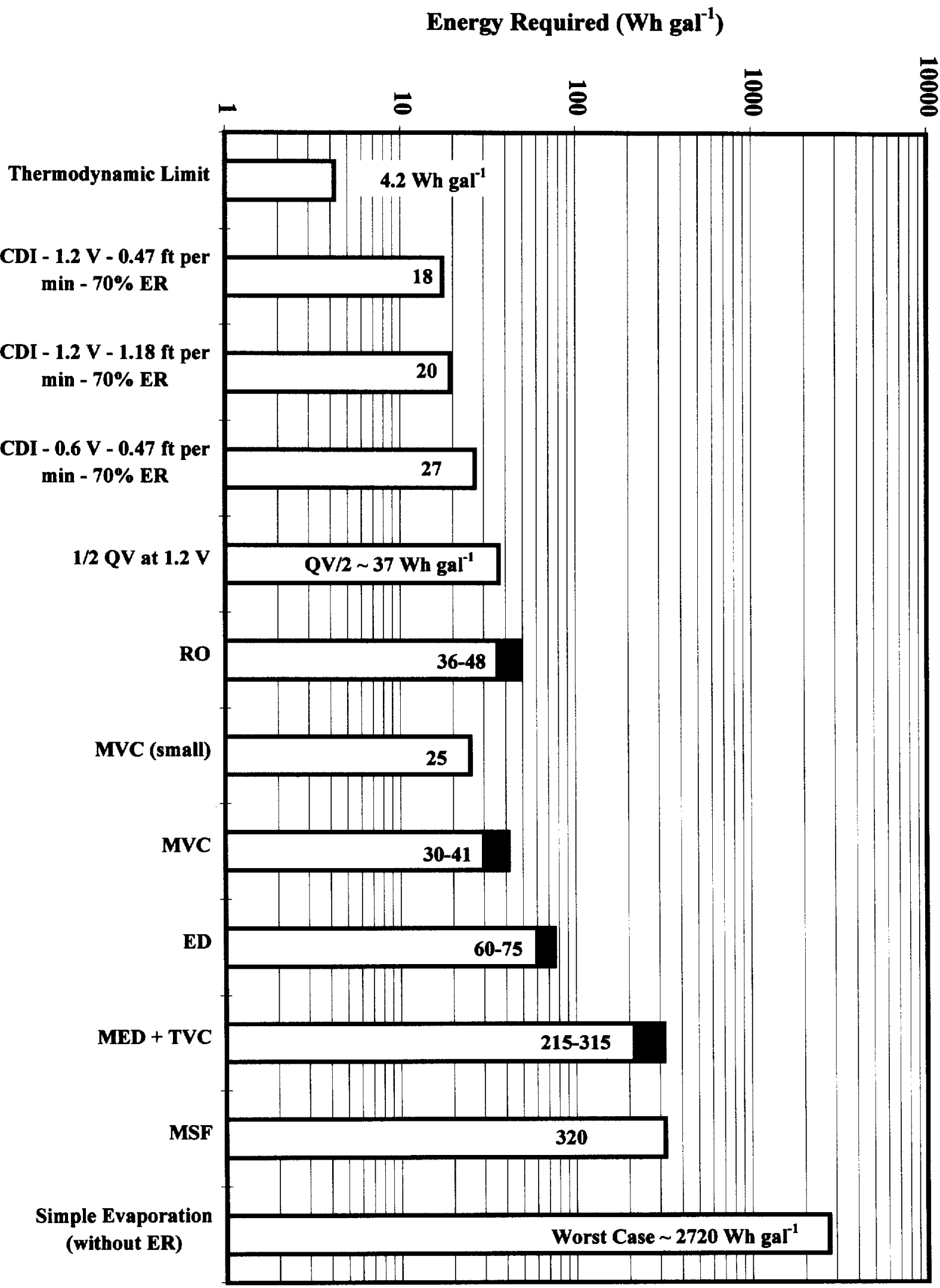




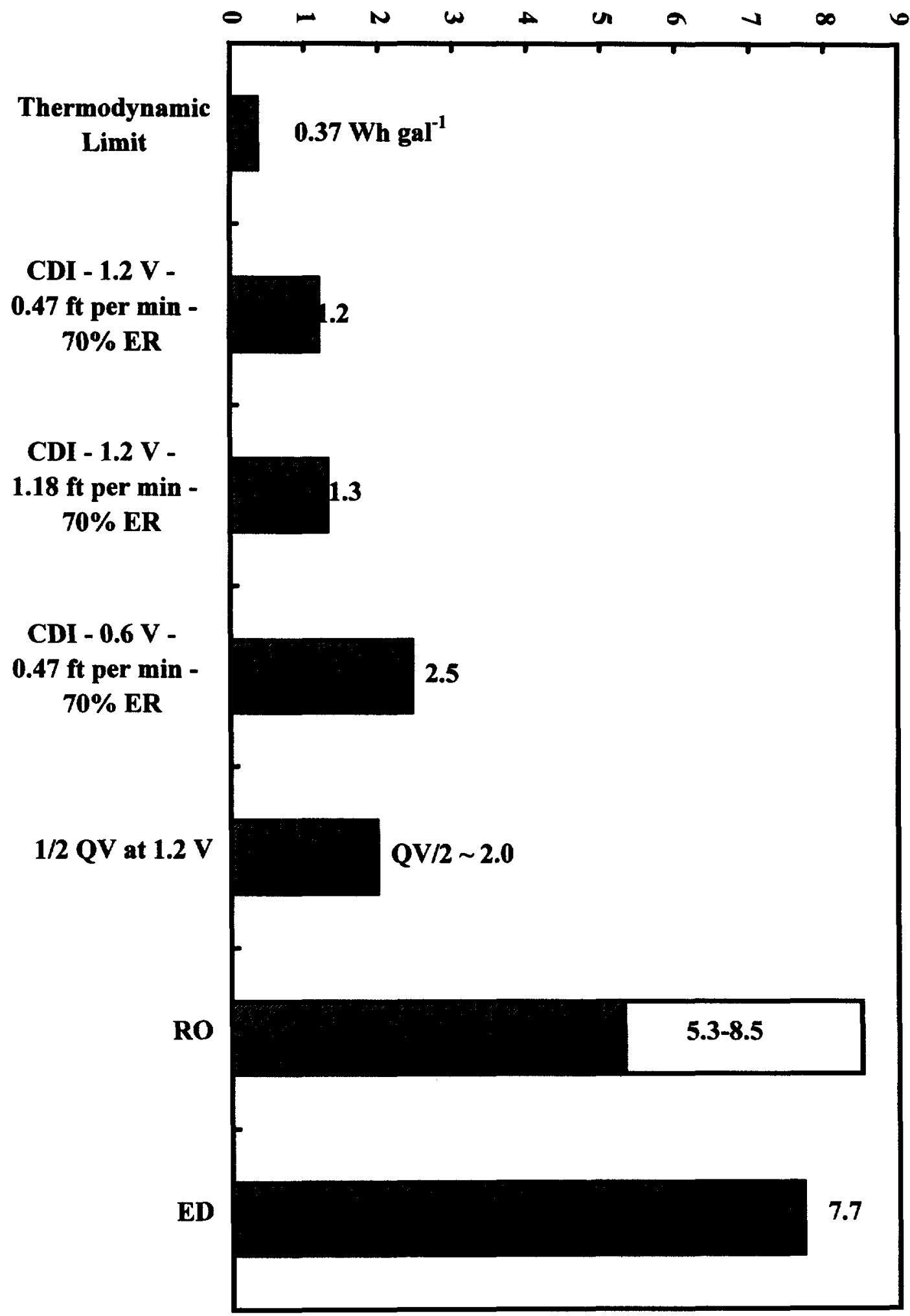




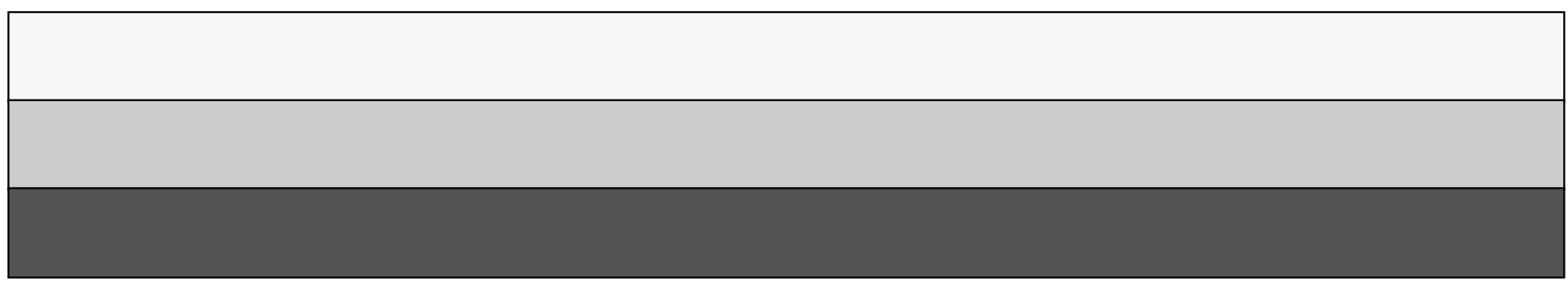

